\title{
A pilot geo-ethnoarchaeological study of dung deposits from pastoral rock shelters in the Monti Sibillini (central Italy)
}

\author{
Natalia Égüez ${ }^{1,2}$ (1) Marta Dal Corso ${ }^{1,3} \cdot$ Magdalena Wieckowska-Lüth $^{3}$. \\ Chiara Delpino ${ }^{4}$ Massimo Tarantini ${ }^{5}$ - Stefano Biagetti ${ }^{6,7}$
}

Received: 22 July 2019 / Accepted: 28 April 2020

(C) The Author(s) 2020, corrected publication 2021

\begin{abstract}
In recent years, ethnoarchaeological studies focusing on herbivore faecal remains within the soils, especially those from goat, sheep and cattle, have shown the importance of their study for identifying socio-economic activities. Thus, an accurate microstratigraphic examination of these deposits can provide us new insights into past land use, site formation processes, activity areas and intensity of use of space, mobility, domestic use of fuel, manuring, and foddering strategies. Mountain landscapes represent a relatively new terrain of investigation for geo-ethnoarchaeology. In this paper, we present a pilot project featuring an applied inter-disciplinary methodology that includes micromorphology, bulk stable isotope analysis $\left(\delta^{13} \mathrm{C}\right.$ and $\left.\delta^{15} \mathrm{~N}\right)$, phytolith, pollen and non-pollen palynomorphs (NPPs) analyses. These were carried out on samples from three high-mountain (up to $1400 \mathrm{~m}$ a.s.l.) pastoral sites located at Monti Sibillini, in the Italian central Apennines. Results show that the presence of anthropic organic-rich deposits, even when poorly preserved, (1) allows for an accurate description of herbivore dung internal characteristics, (2) establishes precise microstratigraphy of anthropogenic deposits and husbandry practices related to intensity of use of space, and (3) gives accurate information about former vegetation and landscape use in the local area. Based on this exploratory ethnoarchaeological approach, we discuss the potential of micro-analyses of archaeological decayed or burnt livestock dung in a small set of samples collected during a initial survey for obtaining insights into the environment and husbandry practices from dung and goat stabling floors in a high-mountain context.
\end{abstract}

Keywords Ethnoarchaeology $\cdot$ Pastoralism $\cdot$ Dung $\cdot$ Micromorphology $\cdot$ Stable isotope analysis $\cdot$ Microfossil analyses Apennines

This article is part of the Topical Collection on Coprolite Research: Archaeological and Paleoenvironmental Potentials

Electronic supplementary material The online version of this article (https://doi.org/10.1007/s12520-020-01076-4) contains supplementary material, which is available to authorized users.

Natalia Égüez

neguezgo@ull.edu.es

1 Graduate School Human Development in Landscapes. Institute for Prehistoric and Protohistoric Archaeology, University of Kiel, 24105 Kiel, Germany

2 Archaeological Micromorphology and Biomarkers -AMBI Lab, Instituto Universitario de Bio-Orgánica Antonio González, Universidad de La Laguna, 38206 Tenerife, Spain

3 Institute for Prehistoric and Protohistoric Archaeology, University of Kiel, 24105 Kiel, Germany
4 Soprintendenza APAB Frosinone, Latina e Rieti, via Pompeo Magno 2, 00192 Rome, Italy

5 Soprintendenza APAB Firenze, Piazza de' Pitti 1, 50125 Florence, Italy

6 CaSEs Research Group, Department of Humanities, Universitat Pompeu Fabra, 08005 Barcelona, Spain

7 School of Geography, Archaeology and Environmental Studies, University of the Witwatersrand, Johannesburg 2050, South Africa 


\section{Introduction}

Mobile pastoralism represents a highly efficient way of land use in mountain areas, where agriculture is not feasible. Availability of pastures in these type of ecosystems is highly variable along the seasons, and accordingly, pastoralists manage the herds on a year-round basis. This results in biological diversity, and ecosystem integrity and resilience (Gann and Lamb 2006). Here, we analyse two rock shelters and a small complex of dry stone huts, used by mobile herders in the Sibillini Mts. in central Italy until recent times. These sites, no longer frequented since the 1980s, have been investigated under a geo-ethnoarchaeological approach to identify the signals left in the soil record by a sheep/goat-based pastoral system in a high-altitude context.

Ethnoarchaeological research programmes on pastoral societies (Biagetti 2019) have been performed in the Italian Apennines (Baker 1999; Biagetti et al. 2008; Morandi and Branch 2018; Padiglione 2012), and in the Italian Alps (Bazzanella et al. 2013; Bazzanella and Wierer 2013; Carrer 2013, 2017; de Guio and Cavicchioli 2011; see also Carrer et al. 2020 for case study between the Italian and French Alps). Similarly, studies on the ethnoarchaeology of highland pastoralism have been conducted in South-Eastern Europe (Arnold and Greenfield 2006; Chang 1993; Nandris 1990; Pelisiak et al. 2018 for a review), and in the Iberian Peninsula (Gassiot et al. 2012, 2014, 2016; GonzálezÁlvarez et al. 2016; López-Merino et al. 2009; Mazzucco et al. 2019; Rodríguez-Antón et al. 2016). The usual approach is to couple archaeological survey and excavation together with microfossil analyses and historical map analysis when possible, but the inclusion of geoarchaeological techniques is still rare.

Geo-ethnoarchaeology, a research strategy that applies methods from geosciences in ethnographic contexts to investigate markers of human activities within sites or landscapes, has found so far little application in European and Mediterranean pastoral contexts (e.g. Migliavacca and Nicosia 2011; Nicolis et al. 2016). In fact, in spite of its recent developments in different areas (see Friesem 2016 and Shahack-Gross 2017 for two recent reviews), geoethnoarchaeology of pastoral sites has been mainly applied in extra-European regions (Égüez et al. 2018; Égüez and Makarewicz 2018; Elliott et al. 2015; Friesem et al. 2014; Gur-Arieh et al. 2018; Shahack-Gross et al. 2003, 2004). This is surprising if we consider that the term "geoethnoarchaeology" was coined for the first time by Brochier et al. (1992) concerning the study of pastoral sediments from recently inhabited caves in the Madonie highlands in Sicily.

In general, geo-ethnoarchaeological research on pastoralism has provided the archaeologists with a tool to build guidelines related to the formation of pastoral archaeological sites (sensu Skibo 2009), through the geo-ethnoarchaeological study of microremains included in dung deposits (i.e. pollen, NPPs, phytoliths, spherulites, oxalate druses) and their association with a microstratigraphic position. By targeting the dung, an unambiguous element of the archaeological record connected with pastoralism, current research aims at recognising the proxies suitable for geo-ethnoarchaeological analyses in order to drive and support the archaeological interpretation.

A defining characteristic of high-altitude areas is its vertical zonation, and the relationship between the different environments (climate, vegetation, soil, etc.) across the belts, and the type and timing of activities that take place (Walsh 2013). It is true that many Mediterranean high-altitude areas are relatively easy to access, and vertical height can be achieved over relatively short horizontal distances. Still, because of the mobile and ephemeral nature of pastoral societies in continuous search for fresh pastures for their livestock, these regions had been seen often as empty or marginal (Barnard and Wendrich 2008). During the last decade, this vision started to vanish, and now, due to the post-colonial turn in the discipline of archaeology, previously marginalised mountain landscapes are now acknowledged and studied in order to build a long-term narrative on the cultural biographies of these uplands, often considering a threefold approach (i.e. archaeological, palaeoenvironmental and ethnographic datasets) (Costello and Svensson 2018; González-Álvarez et al. 2016).

In this paper, we present the results of soil micromorphology, phytolith, pollen, NPP and stable isotope analyses on dung-rich sediment samples collected by Biagetti, Delpino and Tarantini in 2003 during an ethnoarchaeological exploratory survey (Biagetti et al. 2008). The survey aimed at identifying and recording the material evidence of pastoralism in the region surrounding the village of Montemonaco in the Sibillini Mts. Those samples were analysed by Égüez, Dal Corso and Wieckowska-Lüth in 2016-2017 at Kiel University to try to extract as much information as possible by testing a multi-proxy approach on a small set of samples.

\section{Geographical and historical setting}

The Sibillini Mts. is a prominent mountain group of the Apennines in central Italy, whose peaks reach over $2000 \mathrm{~m}$ high. The mountain group has quite varied morphology and is formed by calcareous rocks (limestone), surrounded by hills of marly-arenaceous rocks (Pedrotti 2001). In the montane belt where the sites are located, the climate is suboceanic with precipitation between 1000 and $1600 \mathrm{~mm}$ (Pedrotti 2001 and references therein). Different altitudinal vegetation belts can be distinguished (Pedrotti 2001; Catorci et al. 2010). In the hills, thermophilous mixed-oak woodland can be found, with Quercus pubescens, Quercus cerris, and Castanea sativa (Pedrotti 2001). In the montane areas, up to $1000 \mathrm{~m}$ forests of Ostrya carpinifolia and Fraxinus ornus can be found, 
followed in altitude by beechwoods of Fagus sylvatica currently widespread up to $1750 \mathrm{~m}$ (Catorci et al. 2010), although in the past they reached higher altitudes. Patchy forests of Castanea sativa occur in montane areas with moist and acidic substratum. Currently, the ecological treeline is at ca. $1850 \mathrm{~m}$ a.s.l., above which grasslands expand (Pedrotti 1995, 2001).

Human intervention to create pastures for livestock dates back to ancient times when pre-Roman populations were already exploiting the Sibillini Mts. as a summer transhumance site (Fermanelli 1985; Gobbi 2001). Seasonal use of the Sibillini Mts. for pastoral purposes continues throughout Roman and Medieval times, up to the present day. The inhabitants of the villages located around the Sibillini Mts. traditionally practised transhumance, moving towards western (Tuscany) and south-western lowlands (area of Rome) in winter. In modern times, the transhumance towards lowlands from the pedemontan villages around the Sibillini Mts. is relatively well documented (see Mattioni 1999, pp. 35-45, and references therein) and is related to an expanding economic system that from the 1300s up to the mid-1900s involves movements of increasingly larger flocks (from the 1900s with the use of trucks) owned by a restricted number of local families. Those flocks were moved in the highland grassland in summertime. Yet, the use of Sibillini highlands also included a smaller-scale type of pastoralism, where local farmers practising agriculture at the bottom of the Sibillini Mts. were used to send their small herds of sheep and goats in the Sibillini higlands in summertime (Gobbi 2001). Sibillini highlands represent a complexand so far poorly studied - pastoral landscape, where ancient and contemporary evidences of animal husbandry coexist and overlap; for example, the ancient sheep-track network is still visible today (Avram 2009).

The vegetation in the high-altitude pastures is dominated by Bromus erectus, Brachypodium pinnatum, Asphodelus albus, Viola eugeniae, Valeriana tuberosa, Briza media, and Trifolium montanum, along with Sesleria apennina and Carex kitaibeliana. Less frequent are Androsace villosa, Paronichia kapela ssp. kapela, Hedraianthus graminifolius, Anthemis mucronulata, and Anthyllis montana. Ultimately, Festuca violacea, Luzula italica, Trifolium thalii, Plantago atrata, Hieracium auricula, and Poa alpina are to be found where a thicker layer of soil is preserved (Fermanelli 1985). Finally, riverside vegetation characterised by Salix sp. groves can be found at different altitudes, as well as marsh vegetation in areas with moist substratum (Pedrotti 2001).

\section{The ethnographic sites}

A pilot survey was designed with the support of local experts ${ }^{1}$, aimed at approaching and evaluating the material evidence of

\footnotetext{
$\overline{1}$ The authors are indebted to Sandro Polzinetti, whose deep knowledge of the area permitted access to the ethnographic sites mentioned in this research
}

pastoral use of the Sibillini highlands. The area close to the village of Montemonaco was therefore selected under suggestions from local experts, who remembered the existence of rock shelters and other locales used until very recently (second half of the twentieth century) in summertime. Two rock shelters were recorded in the 2003 survey (Fig. 1). The first shelter (RS1) is located at $1400 \mathrm{~m}$ a.s.1. and is 22 by $10 \mathrm{~m}$ large (Fig. 2). Facing south, it is located a few meters from a trail that runs along the northern side of the valley and further leads to a close (30-min walking) high-altitude pasture set at ca. $1900 \mathrm{~m}$ a.s.l. This path features massive evidence of human intervention, such as boulder arrangments and stone paving (Fig. 3), likely testifying to its importance for seasonal movement of livestock. The second shelter (RS2) faces the valley and is set at the absolute height of about $1100 \mathrm{~m}$ a.s.1. Currently, no visible path leads to this site, located at the end of a steep slope covered by a thick layer of vegetation hiding the cavity and hindering its entrance. The shelter measures $15 \mathrm{~m}$ by $5 \mathrm{~m}$, and it is considerably smaller than RS1 (Fig. 4). A third site (S3) was also visited (Fig. 5), consisting of a set of dry stone huts set in the proximity of highland pastures at ca. $1300 \mathrm{~m}$ a.s.1.. The huts show no evidence of plaster or mortar. Floors of the huts were made of natural soil hardened by trampling.

\section{Main features and use of space at the ethnographic sites}

Both rock shelters (RS1 and RS2) show clear evidence of the use of space. A wire net supported by wooden posts delimitates the outer perimeter of the two sites. In the first rock shelter (RS1), a small opening enables access by animals and people through a wooden sliding door while in the second shelter the entrance is simply indicated by an interruption of the metal fence, roughly halfway through the outer perimeter. Dry stone walls have been recorded at RS1 and RS2, and represent the most substantial architectural feature of both sites. A wall of large stones extending for $12 \mathrm{~m}$ with a maximum height of $1 \mathrm{~m}$ is set inside the perimeter fence at RS1. In RS2, the evidence of a partially collapsed external wall was recognised. RS1 is characterised by a division in two inner areas, with the southern half likely used to keep the livestock, as testified by the occurrence of sheep and goat droppings and a layer of compacted and often-burnt dung. The shelter's wall in this area features clear evidence of polishing due to the rubbing of small stock, while a small round-shaped dry stone fence was likely used to protect livestock kids or newborns. RS2 features a concentration of burnt dung layers in its northernmost half, while the southernmost part looks cleaner and possibly also used by shepherds. S3 consists of dry stone huts that hosted shepherds stopping over during transhumances, and features no delimited areas for livestock that was likely kept free in the natural terrace set in front of the huts. 
Fig. 1 The study area. Top right: map of Italy with the study area (black square); white triangles represent the three ethnographic sites elected (RS1, rock shelter 1; RS2, rock shelter 2; S3, set of dry stone huts) (elaboration: Stefano Biagetti, produced with ESRI ArcMap 10.2.2)

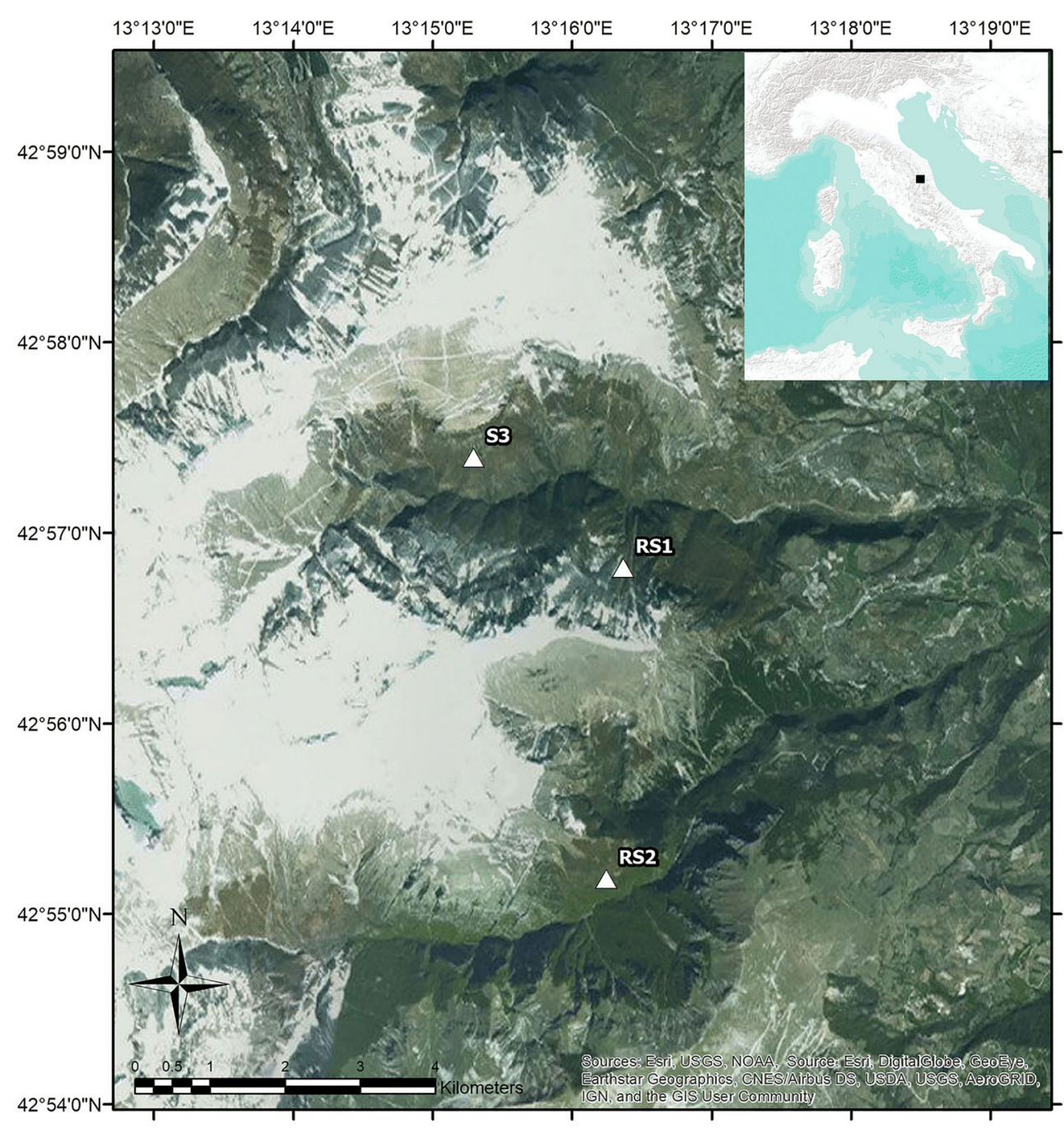

\section{Materials and methods}

Five samples from Sibillini Mts. have been selected: MS1 comes from the floor of one of the dry stone huts in S3, MS2 and MS3 come from the surface floor of RS2, while MS4 and MS5 come from the floor of RS1 (see Figs. 2 and
4 for location). Samples were taken to explore the geological, chemical, and botanical characteristics of pastoral soils in the study area. At RS1, MS4 was collected from the dung area and MS5 from a spot of burnt ground. At RS2, a single bulk sample was taken and later divided into MS2 and 3 for practical purposes, given the thickness of the sample. This allowed

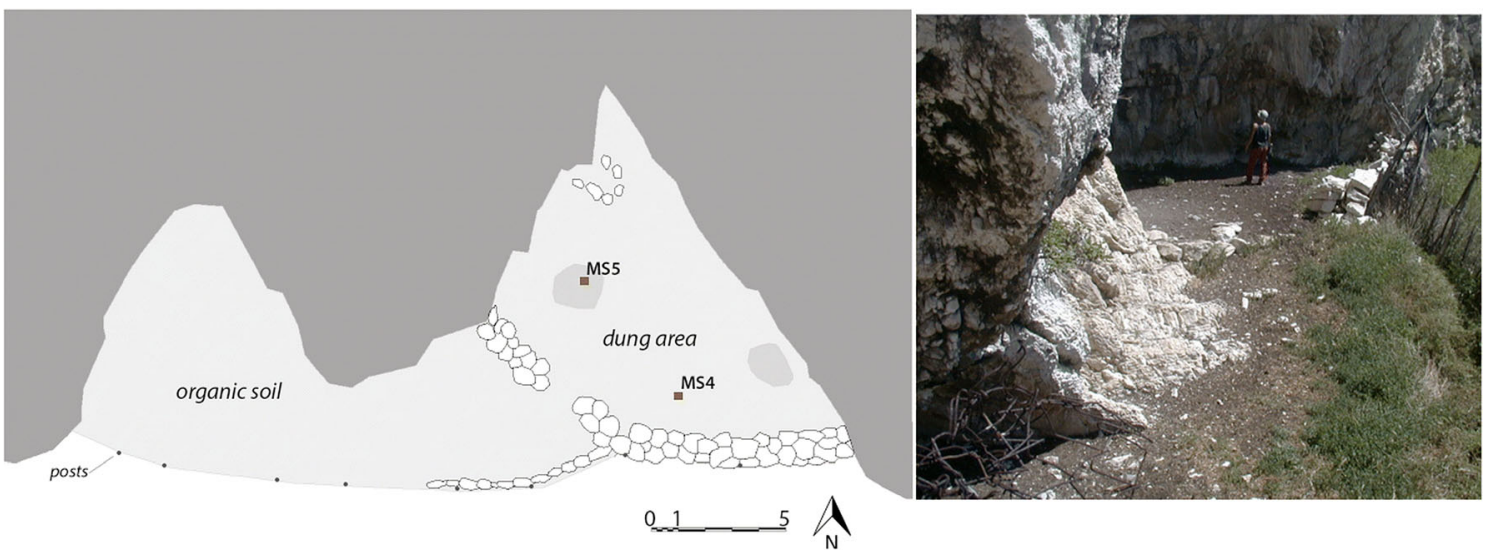

Fig. 2 Sketch (left) and view (right) of rock shelter 1 (RS1) (sketch drawing: Massimo Tarantini; digitisation: Stefano Biagetti; photo: Stefano Biagetti) 


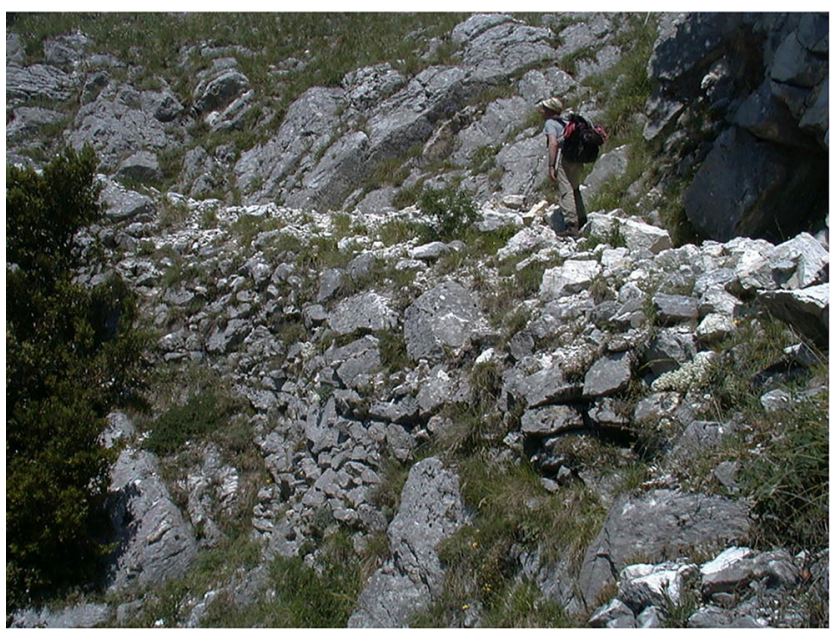

Fig. 3 Part of the path leading to RS1 (photo: Stefano Biagetti)

enhanced geological and chemical analyses (micromorphology, bulk soil analysis, and stable isotopes), while the microfossil analyses were conducted on the single original bulk sample consisting of both MS2 and MS3. Finally, a single sample was extracted from the soil surface of one of the huts in S3. Those samples were subjected to the analyses described below.

\section{Micromorphology}

Micromorphology analysis was conducted on five thin sections (four of $4.8 \times 2.8 \mathrm{~cm}$ and one of $5.5 \times 5 \mathrm{~cm}$, all $30 \mu \mathrm{m}$ thick) prepared from four undisturbed sediment blocks extracted from the surface floors of the three sites: samples MS1 from S3, MS2 and MS3 from RS2, MS4 and MS5 from RS1. They were processed at the Thin Section Service Laboratory (Universitat de Barcelona, Spain), where they were embedded in epoxy resin, cut with an IsoMet lowspeed saw, mounted on glass slides, cut to a thickness of $1 \mathrm{~mm}$ and finally polished to $30 \mu \mathrm{m}$. Microscopic analysis was performed on a polarising microscope (Leica DM2500) at $\times 100, \times 200$ and $\times 400$ magnifications under planepolarised light (PPL), cross-polarised light (XPL), and oblique incident light (OIL). Microphotographs were taken using a

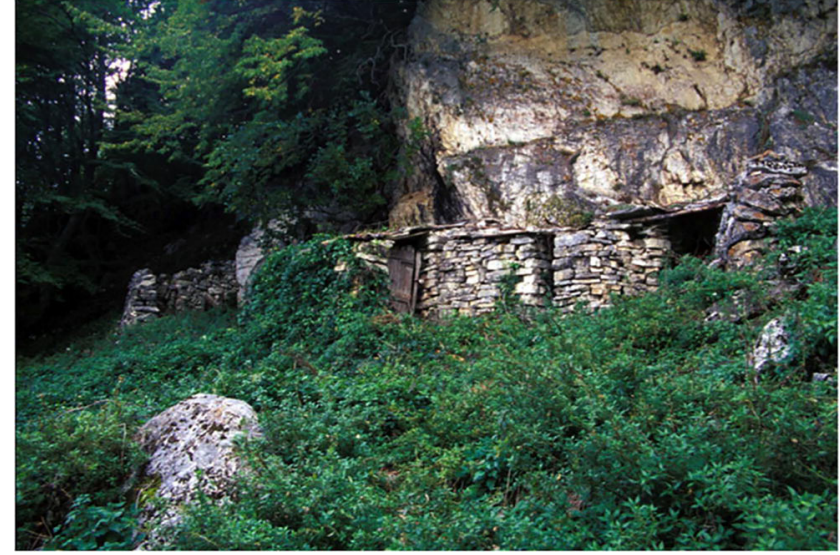

Fig. 5 View of site 3 with the dry stone hut (S3)

Keyence VHX-5000 series digital microscope. Micromorphological descriptions were carried out following guidelines from Bullock et al. (1985), Courty et al. (1989) and Stoops (2003); Stoops et al. (2010) and are included as electronic supplementary material (ESM 1).

\section{Bulk soil analysis}

Five samples of loose sediment were processed for loss on ignition (LOI): sample MS1, MS2, MS3, MS4, and MS5. LOI was used as a proxy for soil moisture, soil organic matter (SOM), charcoal, calcium carbonate $\left(\mathrm{CaCO}_{3}\right)$ and mineral residue (MR). The method involved 4-h cycles of drying at $105{ }^{\circ} \mathrm{C}$ and combustion at $400{ }^{\circ} \mathrm{C}, 550{ }^{\circ} \mathrm{C}$ and $925^{\circ} \mathrm{C}$ (Heiri et al. 2001) and was performed at the Institute for Ecosystem Research of Kiel University.

\section{Phytolith analysis}

Four phytolith samples from the pastoral sites in the Sibillini Mts. were subsampled in the laboratory from the soil blocks used for micromorphology. The samples are named MS1 (from S3), MS2-3 (from RS2), and MS4 and MS5 (both from RS1) after the block they were sampled from. The samples have been processed at the Institute of Pre- and Protohistory of

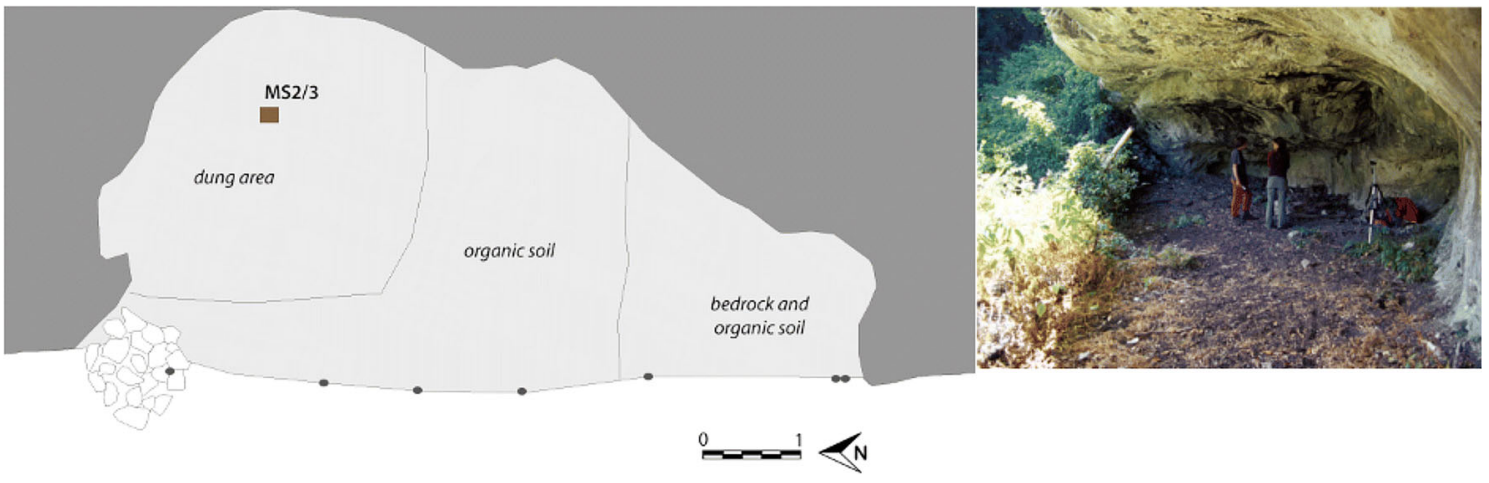

Fig. 4 Sketch (left) and view (right) of rock shelter 2 (RS2) 
Kiel University following the procedure described in Madella et al. (1998). Identification was carried out using a light microscope at $\times 400$ magnification and applying a crosspolarised light filter in order to distinguish biogenic silica from quartz crystals. The slides were also checked for spherulites under a polarised light filter. Spherulites are biomineralised calcium carbonate particles associated with herbivore excrement (Canti 1997). A count of over 300 single-cell phytoliths from identifiable morphotypes has been carried out, providing a base for statistic robust interpretations (Zurro et al. 2016). Indeterminate, fragmented or highly corroded silica bodies ("unidentifiable") were counted as well but excluded from the sum. Every silica skeleton (i.e. multicellular aggregate of phytoliths in anatomical position) has been registered as one count, with the differentiation made on the base of the predominant cell types. The relative abundance of each phytolith morphotype has been established as a percentage of the total sum of identifiable phytoliths, excluding unidentifiable phytoliths and silica skeletons. For excluded morphotypes, the percentage is based on the sum of single-cell phytoliths plus the excluded type (Jenkins et al. 2011). Phytoliths have been classified after their 3D morphology, considering their overall shape and ornamentation. The phytolith nomenclature follows the International Code for Phytolith Nomenclature 1.0 (Madella et al. 2005). Unfortunately, no control soil samples or modern plants from the region were available as reference material. Thus, for this pilot study, identifications were compared with the reference collection of Pooideae cereals in Kiel, the online phytolith reference collection of the University College of London (http://www.homepages.ucl.ac.uk/ $\sim$ tcrndfu/phytoliths.html) and the international "Phytcore" database managed by ERAAUB Universitat de Barcelona (http://www.phytcore.org/phytolith/index.php).

\section{Pollen and NPPs analysis}

To evaluate the potential of the material from Sibillini Mts. for dietary reconstruction and seasonal movements, samples were analysed for pollen and NPPs. The samples were prepared following standard techniques outlined by Moore et al. (1991). Counts were made at $\times 400$, in ambiguous cases at $\times 1000$ magnification. For the identification of Cerealia-type pollen phase, contrast microscopy and the cereal identification criteria according to Beug (2004) were used; the Cerealia-type differs from the wild grass-type mainly by its larger diameter ( $>37 \mu \mathrm{m}$; in pollen analysis a boundary of $40 \mu \mathrm{m}$ is generally applied; Behre 2007) as well as its greater pore diameter (> $2.7 \mu \mathrm{m})$, anulus width $(>2.7 \mu \mathrm{m})$ and anulus thickness $(>$ $2.0 \mu \mathrm{m}$; mostly $3.0 \mu \mathrm{m})$. The calculation of pollen percentages is based on the total terrestrial pollen sum, which is 600 in the case of sample MS1 and 300 in samples MS2-3, MS4 and MS5 due to low pollen concentrations. Nomenclature of pollen types follows Beug (2004) and that of spores Moore et al. (1991). NPPs were identified using a reference catalogue at Kiel University and available literature (Aptroot and van Geel 2006; Booth et al. 2010; Cugny et al. 2010; Dietre et al. 2012; Feeser and O’Connell 2010; Fernández 1993; Gelorini et al. 2011; van Geel 1978; van Geel and Aptroot 2006; van Geel et al. 1983). Nomenclature of NPP types follows the HdV-no. system (Miola 2012). Unknown NPPs found in the samples are termed as "KIU-Xxx" (KIU = Kiel University, Germany).

\section{Bulk stable isotope analysis $\left(\delta^{13} \mathrm{C}\right.$ and $\left.\delta^{15} \mathrm{~N}\right)$}

Four soil sediment samples from the pastoral sites in the Sibillini Mts. have been subsampled in the laboratory from the soil blocks used for micromorphology (MS1, MS2, MS3 and MS4). They were ground in a mortar and pestle, then lyophilised, and analysed at Boston University Stable Isotope Laboratory (USA). The analysis was performed in continuous flow mode for $\% \mathrm{C}, \% \mathrm{~N}, \mathrm{C} / \mathrm{N}, \delta^{13} \mathrm{C}$ and $\delta^{15} \mathrm{~N}$ on a GVI IsoPrime isotope ratio mass spectrometer and a Eurovector elemental analyser, combined with a diluter and reference gas box. Detailed instrumentation and procedure can be found here: http://www.bu.edu/sil/quality.htm. Stable isotope abundance was expressed in standard $\delta$ notation relative to $\mathrm{V}-\mathrm{PDB}$ and AIR (atmospheric N2) for $\mathrm{C}$ and $\mathrm{N}$, respectively. In addition to carbon and nitrogen isotopes from the same sample, continuous flow also reported $\% \mathrm{C}$ and $\% \mathrm{~N}$ data.

\section{Results}

\section{Micromorphology analysis}

Thin sections of all sediment samples show good preservation of vegetal remains: seeds, phytoliths in anatomical connection and stems are visible along with some amorphous vegetal tissue that has preserved intact cellular structures (Fig. 6). The samples contain abundant fragments of sheep/goat excrement, with some oxalate druses, and abundant dung spherulites (Fig. 6f, g). All samples are affected by bioturbation, likely from mesofauna and mites.

In RS1, the area corresponding to sample MS4 shows burnt seed fragments, with a matrix comprised of massive burnt spherulites (darker brown colour in cross-polarised light, with sizes ranging from 20 to $30 \mu \mathrm{m}$ ) and a high degree of trampling indicated by vertical fractures accompanied by the horizontal disposition of all the vegetal micro-remains. Also, there are amorphous charred-like preserved vegetal remains due to the action of fire with minor proportions of other particles, including charcoal fragments and dust. This area also shows the presence of freeze/thaw processes indicated by desiccation marks and channels, and humified appearance of 


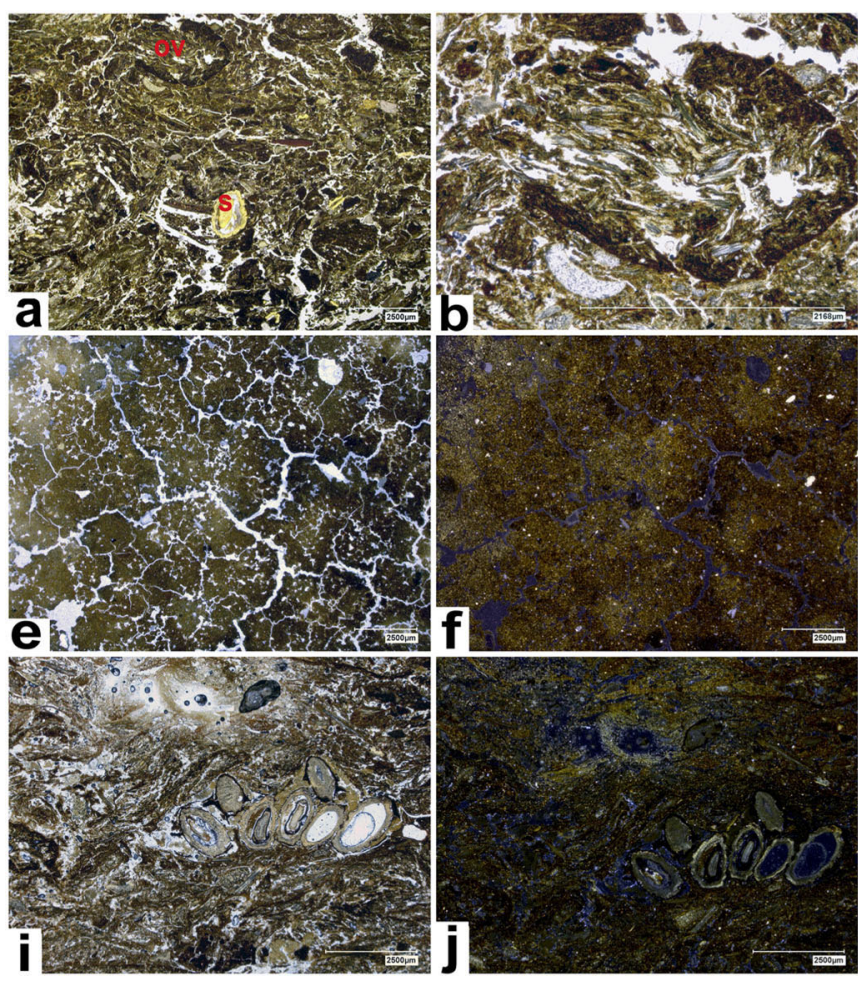

Fig. 6 Microphotographs from thin sections showing main features from $\operatorname{RS} 1(\mathbf{a}-\mathbf{f}), \operatorname{RS} 2(\mathbf{g}-\mathbf{j})$ and $\operatorname{RS} 3(\mathbf{k}, \mathbf{l})$ : a general view of the horizontal disposition of the elements contained within the matrix, also indicating trampling action. In red OV refers to ovicaprine dung pellet and $\mathrm{S}$ to seed. In PPL; $\mathbf{b}$ detail of well-preserved ovicaprine coprolite from a, note the convoluted pattern of the partially digested plant tissue. In PPL; $\mathbf{c}$ detail of well-preserved fruit seed from a. In PPL; $\mathbf{d}$ detail of preserved seed from a. In XPL; e general view of the burnt matrix with cracks related to freeze and thaw postdepositional processes. In PPL; f same as e but in XPL. Note the massive spherulitic appearance of the matrix with bright light

some amorphous vegetal remains, all related to humid conditions at the site (Fig. 6e). Sample MS5 presents well-preserved sheep/goat coprolite fragments rich in lignin and cellulose and inclusions of partially digested phytoliths and with observable convoluted internal structure (Fig. 6b). Also, fruit seeds (cmsized) appear complete and perfectly preserved (Fig. 6c, d). No charcoal fragments were observed. The sediment matrix in this area appears less trampled and undisturbed, although there are indications of erosional processes (i.e. abundant subrounded mineral fraction related to rock wall dismantlement and wind erosion).

RS2 presents abundant fresh vegetal remains (i.e. stems) along common spherulites $(20-30 \mu \mathrm{m})$; the appearance is spongy with matrix voids that were filled with fresh organic matter that has later not been preserved (Fig. 6h). Samples MS2 and MS3 show cellular vegetal tissue together with phytolith beddings and oxalate druses with millimetre-sized. All of these materials are in horizontal dispositions, indicating some degree of trampling, but there are very few vertical fractures, which suggests less intensity in the occupation of this site (Fig. 6i).

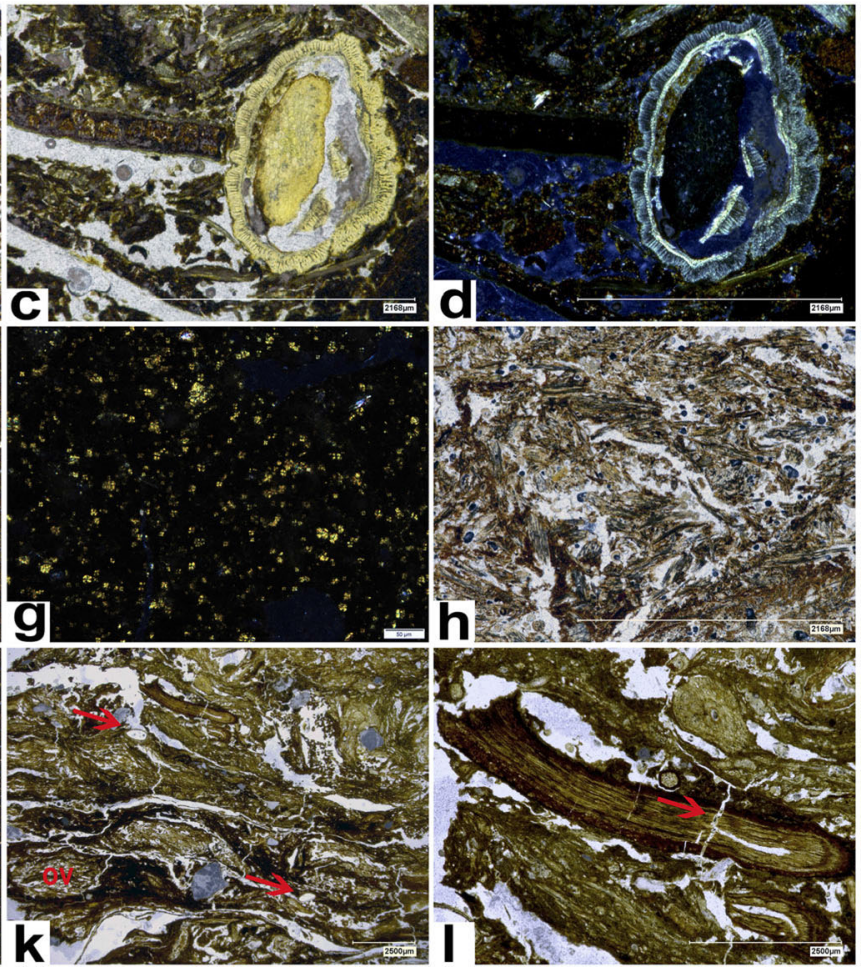

brown colour; $\mathbf{g}$ detail of the spherulites, note they range from 20 to $30 \mu \mathrm{m}$ each. In XPL; h detail of the chaotic matrix of the sediment with phytolith beddings, less trampled (it does not follow a horizontal disposition). In PPL; $\mathbf{i}$ general view of the matrix in RS2 with a group of seven well-preserved fruit seeds. In PPL; $\mathbf{j}$ same as i but in XPL; $\mathbf{k}$ general view of the matrix with signs of very intense trampling (horizontal disposition of the elements and vertical fractures) and presence of parasites (Trichuris sp. eggs) indicated by red arrows. In PPL; I detail of an in situ root microfracture related to trampling, indicated by a red arrow. In PPL, scales are in $\mu \mathrm{m}$ (photos: N. Égüez)

S3 (sample MS1) appears to have intense trampling, indicated by abundant in situ vertical fractures and desiccation marks together with elongated features and the well-layered horizontal disposition of the elements contained in the matrix including abundant amorphous vegetal organic matter with presence of parasites (Trichuris sp.), and subrounded millimetre-sized minerals and spherulitic oxalates (Fig. $6 \mathrm{k}, 1)$. The sediment in the top part of the thin section has a reworked appearance and may indicate raking or cleaning practices on the floor surface. There are subrounded minerogenic calcareous aggregates and plant flecks that are embedded in faecal fragment lenses that are probably an effect of trampling resulting in much mixing and compaction.

\section{Bulk soil analysis}

Results obtained from physicochemical analyses are shown in Table 1. Water percentage is $4.95 \%$ in sample MS4 from RS1, a higher percentage than the other samples. This is in accordance with the humid features of the deposit observed in micromorphology. MS4 also has the highest concentration of 
Table 1 Loss on ignition results showing percentages for water, organic matter, charcoal, carbonate and mineral residue

\begin{tabular}{lllllll}
\hline Context & Sample ID & Water (\%) & Organic matter (\%) & Charcoal (\%) & $\begin{array}{l}\text { Calcium } \\
\text { carbonate (\%) }\end{array}$ & Mineral residue (\%) \\
\hline Dry stone hut (S3) & MS1 & 2.901 & 72.361 & 1.410 & 4.565 & 21.662 \\
Rock shelter 2 (RS2) & MS2 & 3.094 & 72.419 & 1.467 & 5.764 & 20.348 \\
Rock shelter 2 (RS2) & MS3 & 3.582 & 56.913 & 2.431 & 6.183 & 34.472 \\
Rock shelter 1 (RS1) & MS4 & 4.954 & 57.345 & 1.708 & 1.242 & 39.703 \\
\hline
\end{tabular}

mineral residue at $39.70 \%$. On the contrary, it has the lowest calcium carbonate percentage (1.24\%). Samples MS1 and MS2 (S3 and RS2, respectively) have similar values for all residues. MS1 and MS2 have the highest percentages of organic matter $(72.36 \%$ and $72.41 \%$ respectively), so the second rock shelter and the stone hut have similar values. Overall, RS1 has been more affected by pedogenic processes than $\mathrm{RS} 2$ and RS3.

\section{Phytolith analysis}

The morphotypes composing the phytolith assemblages are presented in the histogram in Fig. 7 and counts are included as electronic supplementary material (ESM 2). Microphotographs are shown in Fig. 8. The rich phytolith record in the samples reflects the fact that herbivore dung and dung-rich deposits constitute archives where phytoliths are extremely concentrated (Lancelotti and Madella 2012; Portillo et al. 2014). Phytolith preservation allowed counts between 334 and 363 single phytoliths from identifiable morphotypes (Fig. 7). Silica skeletons with multicellular phytoliths still in anatomical conjunction are also preserved
(Fig. 8g-i, k-n), especially in samples MS2-3 and MS5, suggesting a minor disturbance of the record and more recent deposit formation. Other silica microfossils, such as sponge spicules and diatoms, have not been found, whereas spherulites have been observed in samples MS5 and MS1. Even though dicotyledons do not produce many phytoliths, some morphotypes related to dicotyledonous material are present (7-8\% in MS1 and MS2-3, 2.4\% in MS4 and 5.4\% in MS5), including silica skeletons with isodiametric cells and jigsaw phytoliths (Fig. 8n) observed in trees/shrubs' leaves (Madella 2007; Strömberg 2004).

Most of the phytolith morphotypes are produced by monocotyledons such as grasses and sedges. Although local phytolith studies on modern vegetation are missing, the proportion of grass (Poaceae) short cell phytolith morphotypes (GSCP 53-67\% of the phytolith record; Fig. 8a-d) allows the distinction of different grass subfamilies (e.g. Barboni and Bremond 2009; Blinnikov 2005; Fernandez Honaine et al. 2006; Gallego and Distel 2004; Lu and Liu 2003; Mercader et al. 2010; Piperno 2006; Twiss et al. 1969). Pooideae, the C3 grass subfamily dominant in temperate areas, is indicated here by trapeziform sinuate, trapeziform polylobate and probably

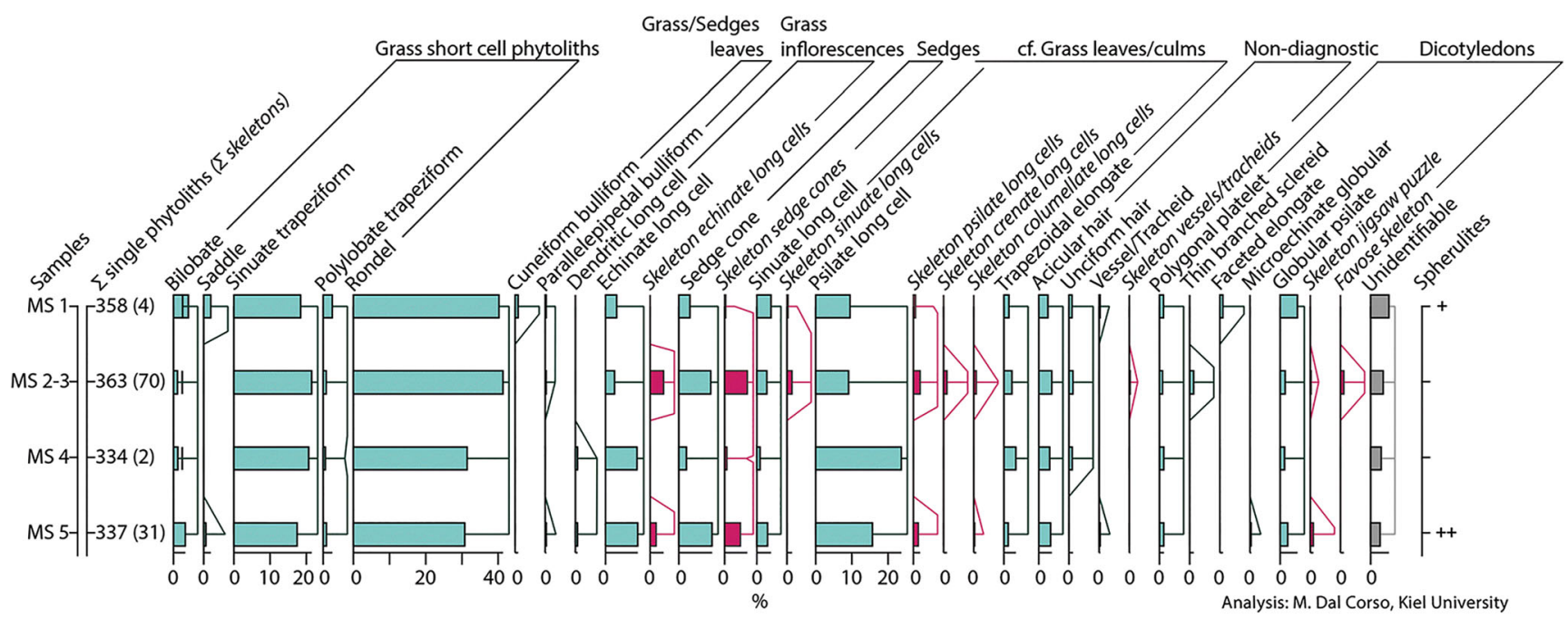

Fig. 7 Diagram with the morphotypes composing the phytolith assemblages. Percentage values are based on at least 300 single-cell phytoliths (excluding unidentifiable and silica skeletons). Multicellular silica skeletons were not very common and have been expressed by a percentage based on the

single-cell phytoliths sum plus themselves. Colour bars refer to silica skeletons (magenta) vs. single-cell phytoliths (light green). Light lines in colour refer to percentage magnification $(\times 10)$. For the attributions to taxonomic plant groups, see literature in the text 

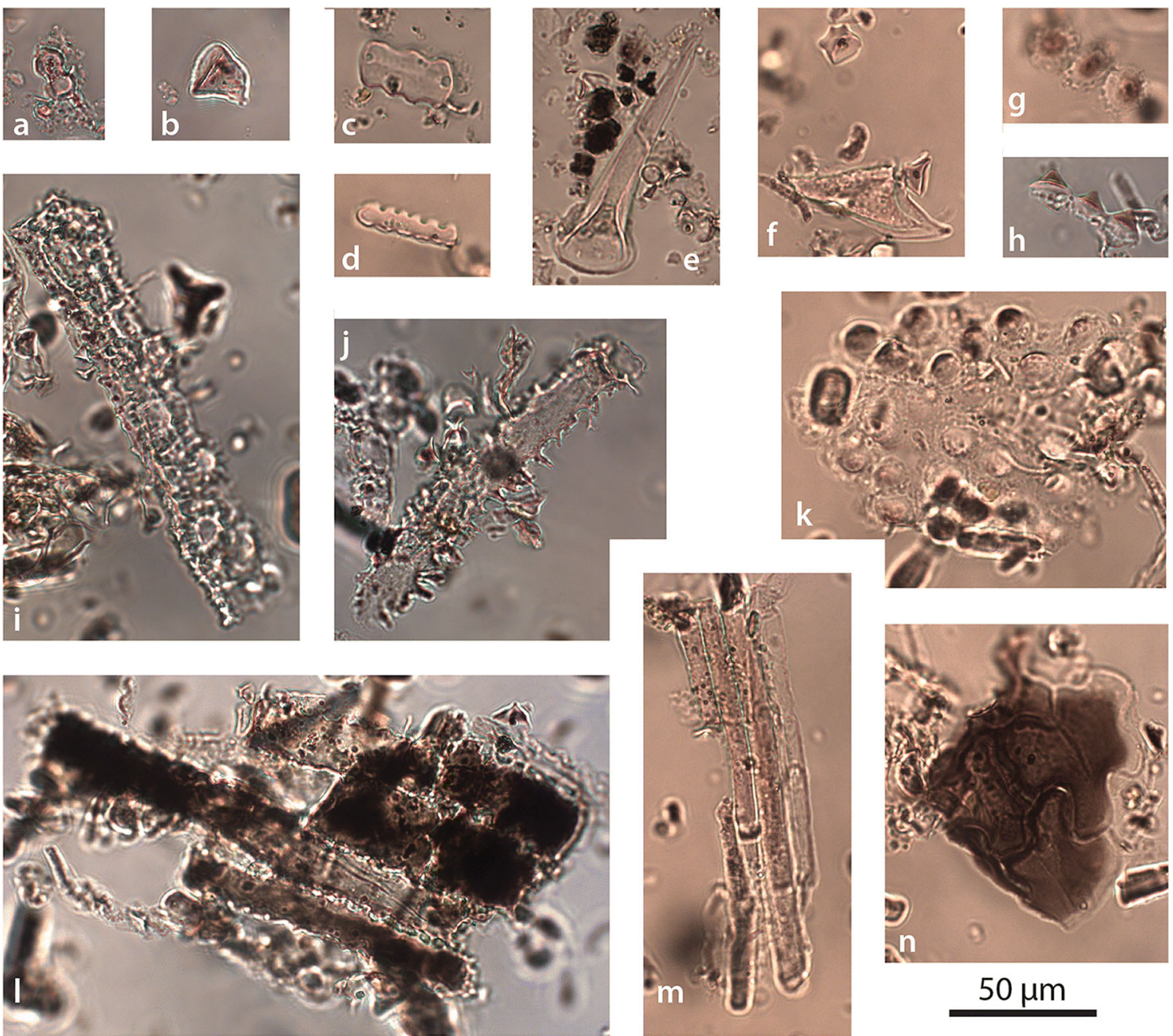

Fig. 8 Micro-photographs of phytoliths as single cells ( $\mathbf{a}-\mathbf{f}$ and $\mathbf{j})$ and silica skeletons with phytoliths in anatomical connection $(\mathbf{g}-\mathbf{i}$ and $\mathbf{k}-\mathbf{n})$ : a bilobate short cell; $\mathbf{b}$ rondel short cell; $\mathbf{c}$ trapeziform sinuate short cell; $\mathbf{d}$ trapeziform polylobate short cell; e acicular hair cell; f unciform hair cell with two rondels; g, h sedge cones; $\mathbf{i}$ silica skeleton composed of echinate long cells with papillae; $\mathbf{j}$ dendritic long cell; $\mathbf{k}$ silica skeleton with papillae; $\mathbf{I}$ darkened silica skeleton with echinate long cells; $\mathbf{m}$ silica skeleton with psilate long cells; $\mathrm{n}$ jigsaw phytoliths (photos: M. Dal Corso) rondels (49-61\%), although rondels are found in minor amounts in other grass subfamilies (Barboni and Bremond 2009). C4 grasses are less common; the Panicoideae subfamily is indicated by bilobate morphotypes (with convex or concave lobe ends, 1.2-4.2\%; Fig. 8a), and the Chloridoideae subfamily is indicated by saddles $(2 \%$ in MS1, $0.6 \%$ in MS5). Bulliform cells, generally produced by the leaves of grasses and sedges (Novello et al. 2012), are present, including cuneiform bulliform $(0.8 \%$ in MS1) and parallelepipedal bulliform $(0.3 \%$ in all samples apart from MS4) types. These bulliform phytoliths are scarce in these samples, but this does not exclude the presence of monocotyledonous leaves. The formation of bulliform phytoliths, which is favourably influenced by environmental conditions such as high evapotranspiration rate (e.g. in moist habitats in arid regions; Bremond et al. 2005; Novello et al. 2012), may have not been common in this environmental context. Furthermore, bulliform cells silicify in a later stage of life of the plant (Moulia 1994), which could have been grazed before silicification in these cases. A variety of phytolith long cell types were observed both as single cells and as multicellular aggregates (or silica skeletons) (Fig. 81, m). Most of these long cells (apart from dendritic long cells) when found as single cells are non-diagnostic and can be attributed to many plant taxa. Therefore, they are often considered taxonomically non-informative, although monocotyledons seem to be the main producers. Psilate, sinuate or echinate long cells conjoined in multicellular aggregates with papillae, stomata and/or short cells (as shown in Fig. 8i) correspond with grass epidermal structures and give indication of specific plant parts (Metcalfe 1960).

The silica skeletons found in this study are concentrated in samples MS2-3 and MS5. There are few skeletons with psilate and sinuate long cells (spanning from $11.8 \%$ in 
MS2-3 to $24.6 \%$ in MS4), usually attributed to the stems/ leaves of Poaceae (Lancelotti and Madella 2012; Madella 2007; Portillo and Albert 2011), where they are very abundant; however, they have also been seen in Poaceae inflorescences and in leaf/culm of Cyperaceae (Novello et al. 2012; Ryan 2011). Many skeletons consist of echinate long cells that, along with papillae, characterise inflorescences of Poaceae (e.g. Tubb et al. 1993; Ball et al. 2016). While echinate long cells (especially high in MS4 and MS5, 9\%) are also found in wild grasses and other grass parts (e.g., Phragmites culm; Ramsey and Rosen 2016), dendritic long cells $(0.6 \%$ in MS4 and MS5) have been regularly observed in the inflorescences of cereals such as wheat, barley and oat (Ball et al. 2016; Portillo et al. 2006; Rosen 1992) and in some wild cereals (in Africa; Novello and Barboni 2015). Therefore, dendritic long cells are commonly used as an indicator of cereal chaff, but their association with inflorescences of large-seeded wild grasses cannot be excluded. The socalled sedge cones typical of sedges (Ramsey and Rosen 2016) are present mostly in MS2-3 (8.8\%) and MS5 (9.2\%), also in multicellular aggregates (Fig. 8h). Hair cells (Fig. 8e, f) with very different shapes and sizes are quite frequent (3.3$4.7 \%$ ). Although not diagnostic, hair cells here probably derived from grasses (Piperno 2006). Vessels and tracheids ( $0.3 \%$ in MS1 and MS5), which occur in both monocotyledons and dicotyledons, are very rare.

\section{Pollen and NPP analysis}

The NPP findings are illustrated in Fig. 9. Pollen and NPP results of the four samples MS1, MS2-3, MS4 and MS5 are presented as a percentage diagram in Fig. 10. The pollen spectra from all sediment samples are dominated by non-arboreal pollen (NAP), indicating that the animals grazed mainly in an open vegetation, characterised by grasses (Poaceae) and diverse herbs, represented by Plantago lanceolata-type, Ranunculus acris-type, Caryophyllaceae, Chenopodiaceae, Helianthemum nummuralium-type, Artemisia, Liguliflorae, Senecio-type, Matricaria-type, Centaurea jacea-type, Centaurea montana-type, Convolvulus arvensis-type, Sanguisorba minor-type, Phyteuma-type and Trifolium pratense-type. The sparse amount of arboreal pollen (AP) reflects forest taxa with mainly Fagus, Pinus, Betula, Quercus pubescens-type, Fraxinus ornus and Ostrya-type. The occurrence of pollen of the evergreen species of Quercus ilex-type probably mirrors the vegetation of the warmer southern slopes. The evidence of Juniperus pollen in samples MS1 and MS4 suggests the existence of juniper stands. Sample MS5 from RS1 did not contain any Juniperus pollen, but Juniperus pollen can be poorly dispersed (Huntley and Birks 1983). Modern studies have shown that even when juniper is locally dominant, Juniperus pollen is quite low in pollen samples (Schofield et al. 2007). In addition, pollen preservation was poor in MS5, so thin-walled Juniperus pollen may not have been preserved. Therefore, the absence of Juniperus pollen in MS5 does not affect the interpretation of juniper stands on the landscape. Sample MS2-3 contains the highest amount of AP including the tree taxa mentioned above as well as Corylus, Carpinus betulus, Tilia, Fraxinus excelsior-type and Juglans. The samples furthermore show some evidence of cultivated plants, represented by Cerealia-type (all samples), Linum usitatissimum-type (MS2-3), Vitis (MS1) and Olea europaea (all samples). The cereal pollen recorded in these samples met all of the criteria established by Beug (2004), so it can be claimed with some certainty that this signal is from cereal plants.

The NPP analysis revealed the presence of several fungal remains. Sporormiella-type (HdV-113; Fig. 9(5)) and Podospora-type (HdV-368; Fig. 9(3)) ascospores occur in almost all samples, representing obligate coprophilous fungi (Comandini and Rinaldi 2004; Kirk et al. 2001; van Geel and Aptroot 2006; van Geel et al. 2003). Other NPPs indicative of the presence of dung are present in all samples, including Sordaria-type (HdV-55A; Fig. 9(1)), Coniochaeta sp. (TM-211; Fig. 9(6)), BRN-7 (cf. Schizothecium conicum; Fig. 9(2)), BRN-6 (cf. Podospora; Fig. 9(4)) and KIU-93 (cf. Rhytidospora; Fig. 9(8)) (Aptroot and van Geel 2006; Blackford et al. 2006; Ellis and Ellis 1988; Feeser and O'Connell 2010; van Geel et al. 2003; Graf and Chmura 2006). Sample MS2-3 features the highest diversity of these fungal spores and is the only sample containing LCE-13 (Fig. 9(14)4), which may be regarded as an indicator of vegetation openness and a grazing indicator (Dietre et al. 2012). The spectra of MS4 and MS5 are furthermore distinguished by the presence of UG-1285 (cf. Ascodesmis sp.; Fig. 9(10)), which is widespread on dung (Gelorini et al. 2011; Hanlin 190). Fungal fruit bodies (KIU-27; Fig. 9(18)) were documented in all samples; however, sample MS1 contained the lowest quantity of the latter, along with coprophilous fungal spores, which may be indicative of dung that was only briefly exposed to fungal growth at this site. In the case of this sample, the dry conditions one would expect for a floor of a dry stone hut may have prevented the full development of dung flora.

All sediment samples are also characterised by the occurrence of eggs of the parasite fluke Dicrocoelium cf. dendriticum (Fig. 9(9)), with the highest quantities present in samples MS2-3 and MS5. Ruminants such as cows and sheep are the definitive host of this parasite (Florenzano et al. 2012), but carnivores and humans can be an accidental host too. Eggs of the intestinal parasite Trichuris sp. (Fig. 9(7)) are present in samples MS1 and MS5, pointing to the deposition of carnivore excrement (van Geel et al. 2003). Another NPP appearing in high proportions in MS4 is KIU-188 (Fig. 9(16)). This type resembles an oocyst of coccidia. These protozoa are obligate intracellular parasites, affecting the 

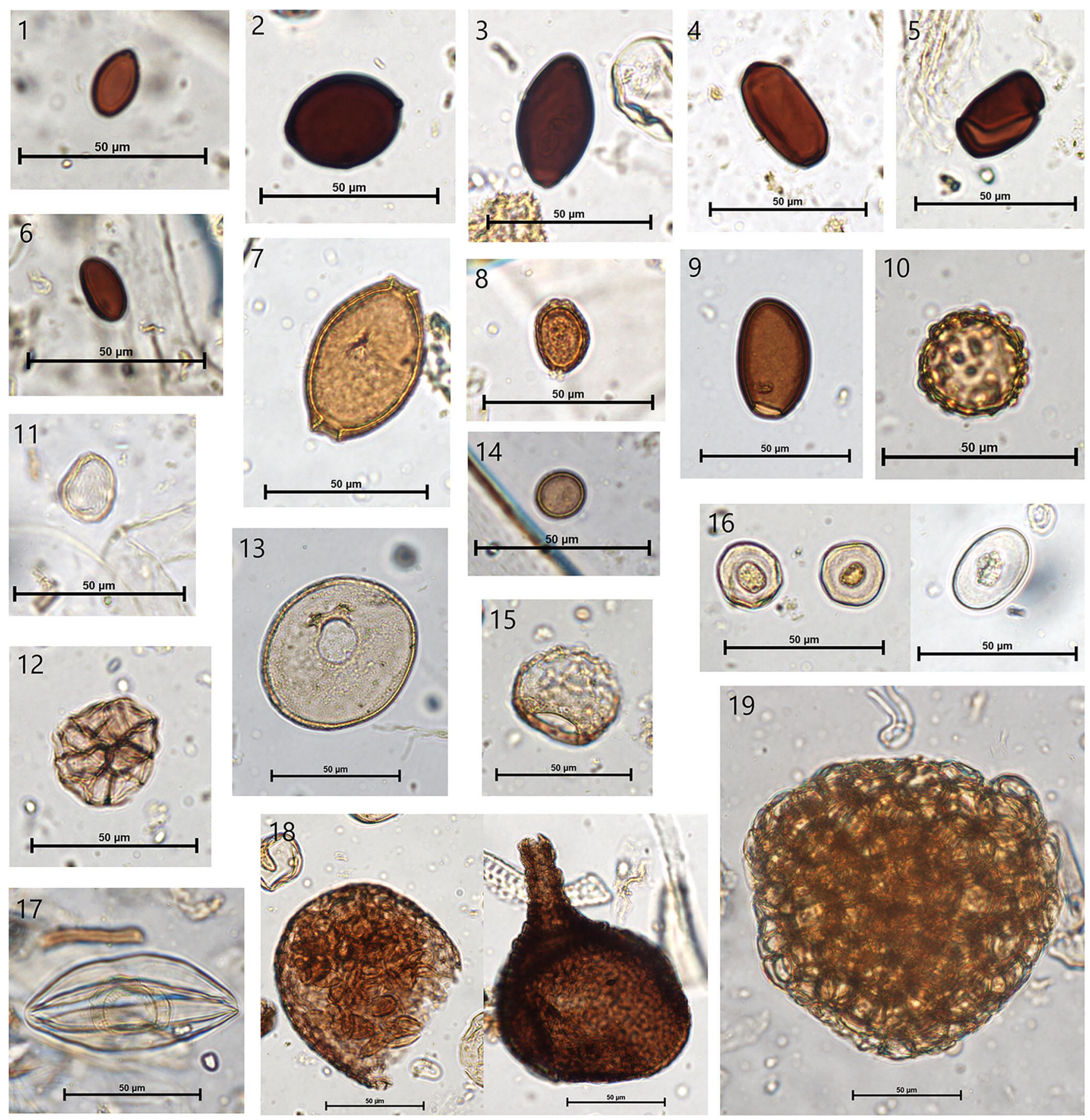

Fig. 9 NPPs from pastoral shelters at Monti Sibillini, Italy. (1) Sordariatype (HdV-55A); (2) BRN-7 (cf. Schizothecium conicum; (3) Podosporatype (HdV-368); (4) BRN-6 (cf. Podospora); (5) Sporormiella-type (HdV-113); (6) Coniochaeta sp. (TM-211); (7) Trichuris sp.; (8) KIU93 (cf. Rhytidospora); (9) Dicrocoelium cf. dendriticum; (10) UG-1285

(cf. Ascodesmis sp.); (11) KIU-195 (cf. Entorrhiza); (12) KIU-194 (cf. HdV-8A); (13) Arcella-type; (14) LCE-13; (15) Cyclopyxis arcelloides; (16) KIU-18 (cf. Coccidia oocysts); (17) KIU-192 (cf. algal spore); (18) KIU-27 (fungal fruit body); (19) KIU-102 (cf. Sorosporium-type) (photos: M. Wieckowska-Lüth)

intestinal tract of animals. Among the coccidia, the genera Eimeria or Isospora cause disease in cattle, sheep, goats, and other domestic animals (e.g. Levine and Ivens 1970). The occurrence of KIU-194 (Fig. 9(12)), which is similar to the fungus HdV-8A - a fungal fruit body, which was recorded together with Eriophorum vaginatum and Sphagnum in a earlier study (van Geel 1978) - is limited to samples MS2-3,
MS4 and MS5. This type shows, for the first time, a positive correlation to Poaceae as host plants, pointing to its ingestion with the grass diet.

The NPP type KIU-102 (Fig. 9(19)) is presented in all samples, while KIU-195 (Fig. 9(11)) occurs only in sample MS2-3. KIU-102 probably represents Sorosporium-type, and KIU-195> may relate to Entorrhiza (HdV-527). Those fungi are 

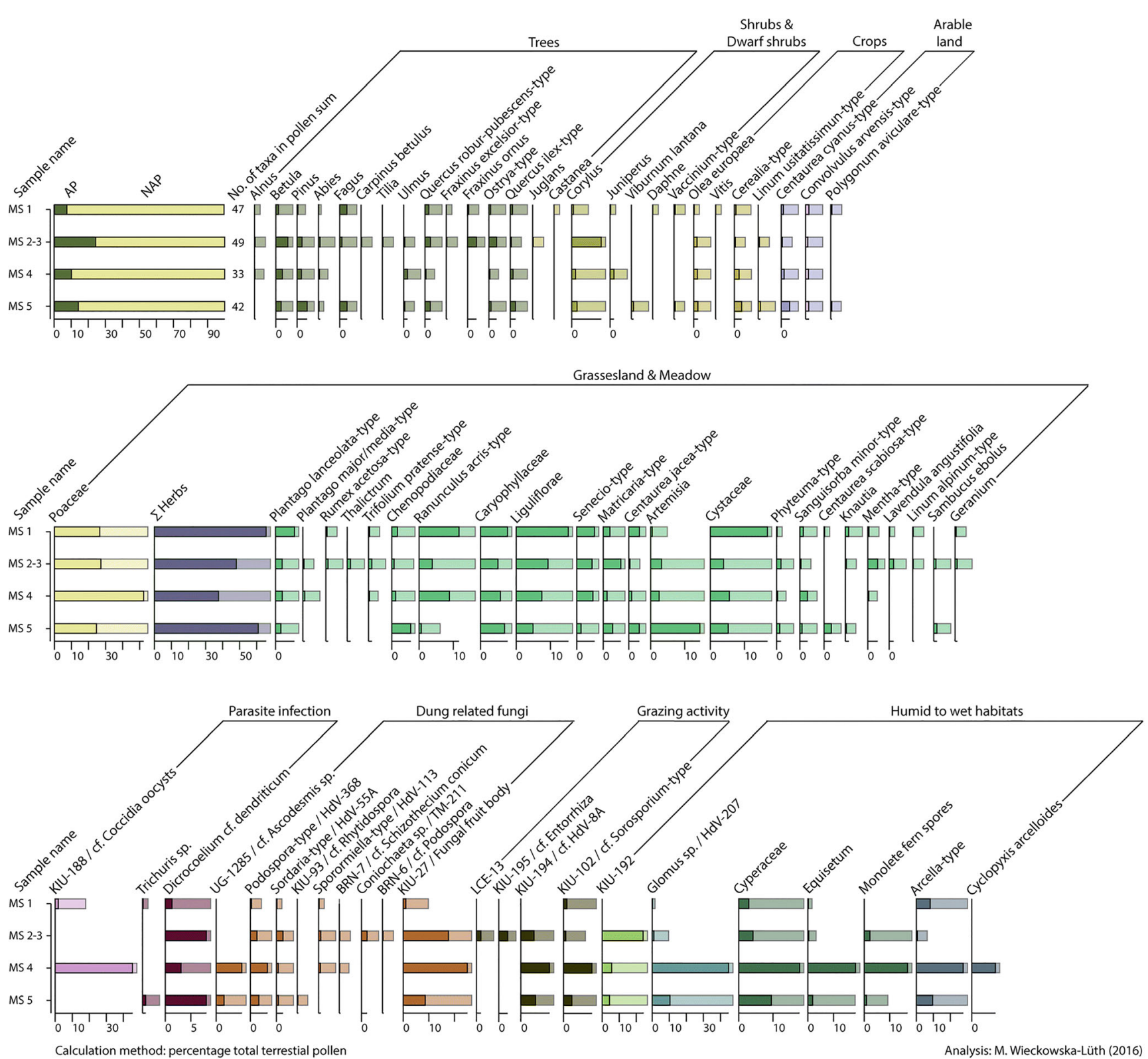

Fig. 10 Pollen and NPP percentages from the dung samples of the pastoral shelters from Monti Sibillini (Italy) showing selected taxa. Percentages are based on the sum of terrestrial pollen (AP + NAP) excluding wetland pollen types. Coloured bars are exaggerated by factor 10

known as plant pathogens; Sorosporium primarily affects grasses (Mudie et al. 2011), while Enthorrhiza affects sedges (Vánky 1994). In accordance with this, KIU-102 was mostly found in the Poaceae dominating spectrum of sample MS4, whereas the presence of KIU-195 was only restricted to sample MS2-3. Overall, these fungi seem to have been present in plants consumed by grazing livestock. Chlamydospores of cf. Glomus (HdV-207) occurred in all samples. Glomeromycota, to which the genus Glomus belongs, has been observed to colonise the roots of different plants of wet habitats (e.g. Kołaczek et al. 2013; Rickerl et al. 1994; Ingham and Wilson 1999; Miller 2000; Weishampel and Bedfor 2006) and its greatest abundance occurs in sample MS4. The same sample is also characterised by the high frequencies of Cyperaceae, Equisetum, monolete fern spores and testate amoebae. The latter is represented by Arcella-type (Fig. 9(13)) and Cyclopyxcis arcelloides (Fig. 9(15)), which inhabit among others moist soils (Booth 2002). Thus, both the NPP and the pollen record reflect within their spectra extensive wetland sites, probably alongside a river, which could be frequented by the animal herds.

\section{Bulk stable isotope analysis $\left(\delta^{13} \mathrm{C}\right.$ and $\left.\delta^{15} \mathrm{~N}\right)$}

Bulk stable isotope analysis from dung-rich sediment samples containing undigested plant remains shows $\delta^{13} \mathrm{C}$ values in the 
range of $\mathrm{C} 3$ (carbon fixation pathway) plants, from -26.67 to $-27.64 \%$, clustering around a mean carbon isotopic distribution of $-27.18 \%$ o (Fig. 11). These values are in accordance with carbon isotope measurements on plant taxa from highelevation landscapes (Körner et al. 1988), and specifically on high altitude and lowland herbaceous taxa of the central Alps (Körner and Diemer 1987). Results for $\delta^{15} \mathrm{~N}$ show ranges between 6.30 and $7.61 \%$, with a mean of $7.02 \%$, falling into the range of known values for other pastoral sites with dung deposits (Abell et al. 2019; Égüez et al. 2018; Shahack-Gross et al. 2008; Marshall et al. 2018).

\section{Discussion}

Transhumant pastoralists use several strategies to exploit climatic variability and maintain relatively high long-term production despite periodic losses of stock in their herds. In these highland-lowland systems, herds are moved in seasonal cycles between fixed points at different altitudes, taking advantage of grazing areas available at different times of the year (Liechti and Biber 2016). In the Sibillini high-altitude landscapes (between 1500 and $2450 \mathrm{~m}$ a.s.l.), the grazing season on pastures starts in June and lasts until the beginning of autumn (D'Ottavio et al. 2004). Here we use multiproxy data from this study to provisionally interpret season of occupation for the rock shelter (RS1 and RS2) and stone hut (S3) sites (see Fig. 12 for a model based on our results).

Samples from RS1 show presence of Juniperus pollen in sample MS4 suggesting over-grazing in some locations, and thus, indicating the ingestion of plants in a more open environment. In areas with heavy grazing, juniper is often the only tree to occur, because grazing animals do not eat it, due to its protective mechanisms (e.g. needles) (Miller and Rose 1995). Also, according to the microfossil assemblages, containing evidence of plants of wet habitats as well as other organisms inhabiting wet soils, the herd had concomitantly frequented locations with water input at lower altitudes, where the livestock fed on wetland vegetation and quenched its thirst. On steep slopes with discontinuous coverage, another good kind of pasture can be found dominated by sedges and grasses (see pasture type 1 with Sesleria tenuifolia and Carex kitaibeliana; D'Ottavio et al. 2005), both very abundant in this sample. The phytolith samples from this location are characterised by abundant echinate long cells from grass inflorescences, which have been accumulated in the heavily trampled dung deposit. Altogether, this suggests sheep/goat flocks consistently stopping by RS1 after grazing in open grasslands during the late summer months (see Fig. 12), when the grasses present fully developed inflorescences. The very high frequency of grass pollen and grazing-related NPPs supports this interpretation. Cerealia-type pollen and very few phytolith dendritic long cells from cereal inflorescences are present in RS1. These microremains most likely derive from ears of cereals such as wheat or barley, although with an unsure determination of the species. In such low percentages, and in such geographical context, these cereal micro-remains do not indicate local cultivation, which is indeed not practised at high altitudes in these mountains. They suggest instead the vertical mobility of the sheperds and their animals, which act as dispersal agent, by carrying some cereal ears, or the micro-remains, attached to clothes, wool or fur when coming from or passing through areas with cereal cultivation at lower altitudes. It is also possible that these micro-remains are derived by cereal plants growing spontaneously in the site due to transport and deposition of undigested seeds from ruminant dung pellets that would freely graze at lower altitudes where cereal cultivation occurs (e.g. at the border of fields). However, we discard this option because cereal grains have not been observed in thin section and their preservation after digestion would have been compromised. Cereal grains could survive and appear completely undigested in cattle dung (Wallace and Charles
Fig. 11 Biplot showing the bulk carbon and nitrogen isotope values from the four soil samples: $\mathrm{MS} 1=\mathrm{RS} 3, \mathrm{MS} 2=\mathrm{RS} 2, \mathrm{MS} 3=$ RS2, MS4 = RS1. The $\delta^{13} \mathrm{C}$ isotopic composition in all samples falls into the range of $\mathrm{C} 3$ plants (ca. -26.6 to $-27.8 \%$ ). Note the higher ${ }^{15} \mathrm{~N}$ values for MS1 and MS3, contexts rich in organic matter and fungal activity

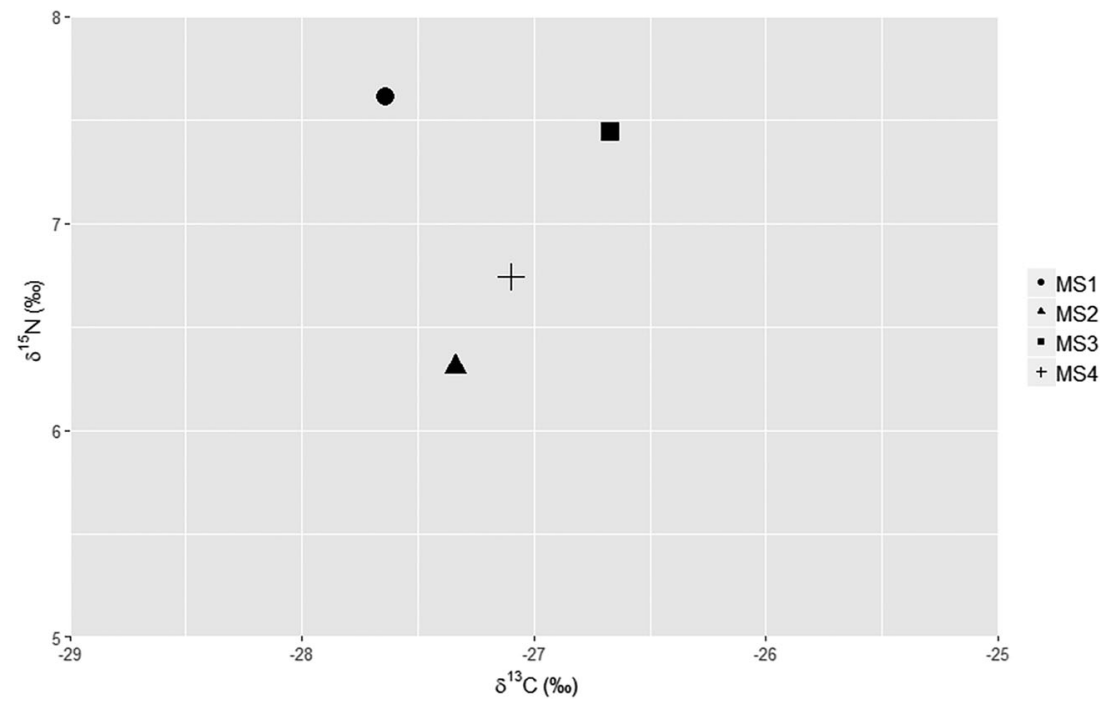


$\mathbf{N}$

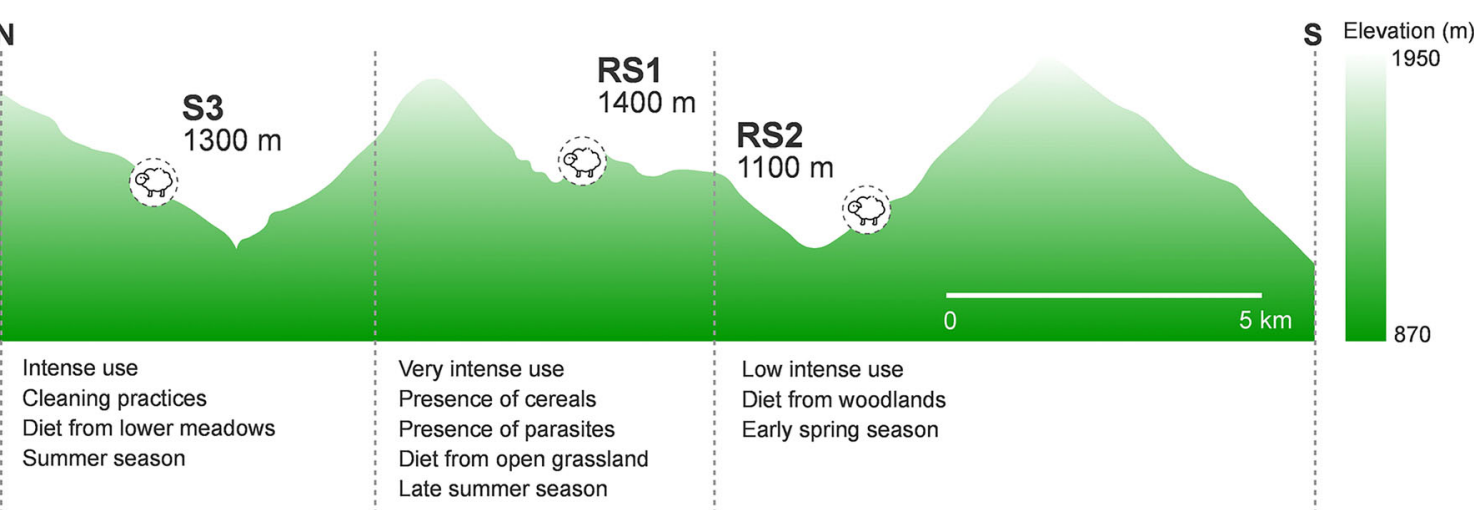

Fig. 12 Elevation profile showing the location of the three sites analysed with an overview of the main interpretation of results. Sources: elevation profile from Google Earth Pro; sheep vector image from Knitting package available in Flaticon.com

2013) but studies related to sheep and goat dung show that only glume bases are preserved after digestion, and are only observable at the microscale (Spengler 2019 and references therein). In our samples, the micromorphological observation of the dung pellets micro-fragments in the thin section does not support the evidence of cattle herding in RS1 (and neither in any of the other sites analysed) but those of sheep and/or goat. The cereal microremains might also be included in animal droppings, but the deliberate feeding of cereal chaff to the livestock so close to the pastures seems unlikely, and in such case, much higher percentages of cereal-related micro-remains would be expected in the samples. Additional study of the local grass vegetation from these deposits (e.g. through macro-remains) and of modern reference material is needed to explore the chance that dendritic long cells and Cerealia-type pollen derive from wild largeseeded grasses, which for now cannot be ruled out. Finally, traces of the intestinal parasite Trichuris sp. in sample MS5 points to the deposition of excrements of carnivores (van Geel et al. 2003), probably of shepherd dogs, in the front part of RS1 (Fig. 12). The evidence of this helminth, however, may also demonstrate the deposition of human faeces or, respectively, of wild carnivores inhabiting the site after it has been abandoned by the sheperds and their animals.

The second rock shelter, RS2, is located in a difficult to reach lower location, with a surface covered with sheep/goat dung pellets. It presents quite reworked soil sediment due to mesofaunal bioturbation and shows traces of less intensity in the trampling. Despite the indented and protected shape of the shelter, the input of some airborne pollen and the influence of local vegetation (e.g. Matricaria/chamomile pollen) cannot be excluded. However, the micro-remains record likely reflects the diet of the herbivores enclosed in the dung content, as suggested by the presence in sample MS2-3 of the highest diversity of coprophilous fungal spores, thus supporting the evidence of a sheep/goat dung deposit described in the micromorphological analysis. The variety of spores may be indicative of dung that has been exposed for a long time before fossilisation (Krug et al. 2004; Aptroot and van Geel 2006).
Concerning the plant spectrum, the sample from MS2-3 is characterised by the highest percentage of arboreal pollen (and variety within) and by some phytoliths associated with dicotyledonous plants that may represent the leaves of trees and shrubs. A previous study reported a similar percentage of dicotyledonous plant material phytoliths distinguishing dung samples from sheep/goats that browsed on tree and shrubs leaves (Elliott et al. 2015). This site is located at a lower altitude from RS1, in an area surrounded by broadleaved woods. The data recovered suggest that animals grazed in the forest at these lower altitudes. Among the trees, Fraxinus ornus, Ostrya and Olea europea are Mediterranean deciduous trees. The first two are good providers of leaf fodder, and thus could have been possibly grazed when having fresh leaves and flowers, which would occur from the end of March to the mid of May (with pollination peak in April) according to the closest pollen calendar (station for aeropalynology of Castel di Lama, Ascoli Piceno, dataset 2010-2018; www.pollnet.it/ Stations/cal_it_22.aspx). Betula and Corylus are pioneering and light-demanding plants, which could indicate woodland openings. Moreover, they are among the first trees to flower (end of March beginning of May for birch, January-March for hazel; www.pollnet.it/Stations/cal_it_22.aspx), suggesting that animals may have been brought to this site in early spring (Fig. 12). In addition, the pollen record shows the use of open pastures, suggested in particular by the presence of some plants that are preferred by sheep, i.e. red clover (Trifolium pratense-type) and Senecio (Senecio-type) (D'Ottavio et al. 2004). These types are also present in samples from RS1 and S3, suggesting use of open pastures at these sites as well. Red clover is found in pastures on flat ground close to hollows or on stable slopes of high-altitude areas where snow melts late. These are areas that present maximum coverage of grass and herbs and have very high pastoral nutrition value (e.g. pasture type 11 dominated by Festuca nigrescens, Plantago atrata and Crepis aurea ssp. Glabrescens; D'Ottavio et al. 2005). The use of diverse kinds of pastures fits to recent practices in the area of Castelluccio di 
Norcia (Perugia), where sheep flocks were given access to different pastures for altitude, topography and plant productivity (D'Ottavio et al. 2004). It was observed that animals tend to select and overgraze the pasture with higher grazing values, e.g. legume-rich types such as red clover (D'Ottavio et al. 2004; Scotton et al. 2005).

The third site, S3, represents a dry stone building used by shepherds as a refuge and a place to stable sheep and goat herds. The presence of domestic animals is corroborated by the observation of periodic surface cleaning practices. This was likely performed to remove dung accumulations on the stabling floor in order to reduce its volume and to eliminate parasites, a common practice performed since the early Neolithic in numerous sites in Western Europe (Boschian and Montagnari Kokelj 2000; Angelucci et al. 2009; Vergès et al. 2016). This site also shows traces of intense trampling probably caused by the common repeated seasonal use of space. The micro-remains records from this site represent a broad spectrum of plants including some cultivars (grape, olive and cereals, most probably related with anthropic input) and many herbs living on ruderal and trampled areas (e.g. pollen of Liguliflorae and Plantago lanceolata-type). This varied flora, mostly related to anthropogenic indicators (Behre 1981; for Italy, see Mercuri et al. 2013), attests a major influence of human activities on deposit formation at this site. The high frequency of Cistaceae, Liguliflorae and Ranunculus acris-type pollen suggests either the presence of pastures nearby, either the collection of plants from extensive meadows, either that (some) animals were kept at the site after having grazed in pastures. Possibly, the pollen record indicating open grasslands and meadows derives from the sheep and goat dung pellets of animals grazing in that type of contexts during the summer season, and/or that the hut was used to store some hay fodder collected in those months, and specifically, in early summer as observed in ethnographic studies in the Sibillini (Brozzetti 1953) (Fig. 12).

\section{$\delta^{15} \mathrm{~N}$ values in stabling deposits}

Bulk nitrogen isotopic compositions have been applied for the identification of dung remains or stabling floors (ShahackGross and Finkelstein 2008; Shahack-Gross et al. 2008; Marshall et al. 2018). Here, we use the $\delta^{15} \mathrm{~N}$ values as an indicator of dung input into the natural soil sediments. All of our samples have $\delta^{15} \mathrm{~N}$ values above $6 \%$, coherent with soil organic nitrogen derived from herbivore dung and urine and with past livestock enclosure sediments (Shahack-Gross et al. 2008). Bulk sediment $\delta^{15} \mathrm{~N}$ reported values for coastal marine regions range 5-6\%o, while for sediments from temperate terrestrial soils are 1-5\%o (Brown and Brown 2011; Natelhoffer and Fry 1988). However, dung-rich sediments are expected to have higher ${ }^{15} \mathrm{~N}$ values because dung is comprised of a mixture of excreted undigested plant material (rich in lignin and cellulose tissue) and protein-derived material from the animals themselves that is ${ }^{15} \mathrm{~N}$-enriched (Marshall et al. 2018).

Two samples have $\delta^{15} \mathrm{~N}$ values above 7\%o: MS1 (S3) and MS3 (RS2). Remarkably, both are coincident with the high values of organic matter in the LOI analysis. The nitrogen isotopic composition and presence of parasites for $\mathrm{S} 3$ indicate input of dung accumulation, and for RS2 a high presence of fungal activity because of dung deposition in a wetter context. Studies have shown that the microbial biomass and microbial metabolites are enriched with ${ }^{15} \mathrm{~N}$ because the nitrogen in the organic matter is associated with products of microbial origin that have already increased $\delta^{15} \mathrm{~N}$ values (Makarov 2009). Thus, these two areas display a $1-2 \%$ increase due to the addition of another trophic level in the soil related to the microbial decomposers' source.

\section{Conclusion}

The integration of different methods to the study of dung remains led to a valid multi-proxy approach, still rarely applied in high-altitude mountain settings. Such an approach has been able to identify seasonal occupations in relation to different vegetation belts used for pastoral practices in the Sibillini Mountains: an early start of grazing of pastures in spring at the altitude of $1100 \mathrm{~m}$ a.s.l., and then a continuous graze in pastures at higher elevations (1300-1400 m a.s.l.) until the end of the summer season. The use of multiple sources of information calibrated the significance of the single proxies and enabled detection of new ecological information concerning some unknown NPP types. Comparison of phytolith and pollen data enabled determination of the presence of local plant material derived from grasses or sedges versus long-distance airborne pollen contribution. These combined botanical analyses offered hints to seasonality that together with micromorphology and carbon and nitrogen isotope analyses defined the provenance of the plant material, intensity of occupation and the level of preservation of the deposit. More extensive geo-ethnoarchaeological investigations on pastoral deposits of mountain areas will help with the identification of local dynamics vs. more general patterns in the formation and preservation of the record related to animal husbandry. Our findings prove the virtues of using a micro and molecular-based research strategy for pastoral deposits and provide a methodological basis for future investigations of a broader range of archaeological contexts.

Acknowledgements The authors would like to thank the three anonymous reviewers whose comments have greatly improved this manuscript.

Funding information Open Access funding enabled and organized by Projekt DEAL. This work was supported by a PhD scholarship granted to NE from the Graduate School "Human Development in Landscapes" (Christian-Albrechts-Universität Kiel) in the frame of the German Universities Excellence Initiative (grant number GSC 208). 
Open Access This article is licensed under a Creative Commons Attribution 4.0 International License, which permits use, sharing, adaptation, distribution and reproduction in any medium or format, as long as you give appropriate credit to the original author(s) and the source, provide a link to the Creative Commons licence, and indicate if changes were made. The images or other third party material in this article are included in the article's Creative Commons licence, unless indicated otherwise in a credit line to the material. If material is not included in the article's Creative Commons licence and your intended use is not permitted by statutory regulation or exceeds the permitted use, you will need to obtain permission directly from the copyright holder. To view a copy of this licence, visit http://creativecommons.org/licenses/by/4.0/.

\section{References}

Abell JT, Quade J, Duru G, Mentzer SM, Stiner MC, Uzdurum M, Özbaşaran M (2019) Urine salts elucidate Early Neolithic animal management at Așıklı Höyük, Turkey. Sci Adv 5(4):eaaw0038

Angelucci DE, Boschian G, Fontanals M, Pedrotti A, Vergès JM (2009) Shepherds and karst: the use of caves and rock-shelters in the Mediterranean region during the Neolithic. World Archaeol 41(2): 191-214

Aptroot A, van Geel B (2006) Fungi of the colon of the Yukagir Mammoth and from stratigraphically related permafrost samples. Rev Palaeobot Palynol 141:225-230

Arnold ER, Greenfield HJ (2006) The origins of transhumant pastoralism in temperate Southeastern Europe. BAR International Series 1538, British Archaeological Reports

Avram M (2009) The legacy of transhumance in National Park of Abruzzo, Lazio and Molise (PNALM): rediscovery and exploitation. GeoJournal of Tourism and Geosites II 2(4):153-159

Baker F (1999) The ethnoarchaeology of transhumance in the Southern Abruzzi of Central Italy- an interdisciplinary approach. In Bartosiewicz L, Greenfield HJ (eds) Transhumant pastoralism in Southern Europe. Recent perspectives from archaeology, history and ethnology. Budapest, Archaeolingua, 99-110

Ball T, Chandler-Ezell K, Dickau R, Duncan N, Hart TC, Iriarte J, Lentfer C, Logan A, Lu H, Madella M, Pearsall DM, Piperno DR, Rosen AM, Vrydaghs L, Weisskopf A, Zhang J (2016) Phytoliths as a tool for investigations of agricultural origins and dispersals around the world. J Archaeol Sci 68:32-45

Barboni D, Bremond L (2009) Phytoliths of East African grasses: an assessment of their environmental and taxonomic significance based on floristic data. Rev Palaeobot Palynol 158(1):29-41

Barnard H, Wendrich W (2008) The archaeology of mobility: Old World and New World nomadism. Cotsen Insitute of Archaeology, Univ. of California

Bazzanella M, Wierer U (2013) The shelters Mandra di Dos Capel and Trato and the beginning of pastoralism in Fiemme Valley, Trentino (Italy). In Lugli F, Stoppiello A, Biagetti S (eds) Ethnoarchaeology: current research and field methods, Conference Proceedings, Rome, Italy, 13th-14th May 2010. BAR International Series 2472, Archaeopress, Oxford, pp 181-186

Bazzanella, M., Kezich, G., Pisoni, L. (2013): Shepherds' writings and shepherds' life on Monte Cornón (Valle di Fiemme, Trentino). An ethnoarchaeological perspective. In Lugli F, Stoppiello A, Biagetti S (eds) Ethnoarchaeology: current research and field methods, Conference Proceedings, Rome, Italy, 13th-14th May 2010. BAR International Series 2472, Archaeopress, Oxford, pp 174-180

Behre K-E (1981) The interpretation of anthropogenic indicators in pollen diagrams. Pollen et Spores 23:225-245

Behre K-E (2007) Evidence for Mesolithic agriculture in and around central Europe? Veg Hist Archaeobotany 16:203-219
Beug HJ (2004) Leitfaden der Pollenbestimmung für Mitteleuropa und angrenzende Gebiete. Pfeil, München

Biagetti S (2019) Ethnoarchaeology of pastoral societies. In: Encyclopedia of Global Archaeology, 1-11

Biagetti S, Delpino C, Tarantini M (2008) Ethnoarchaeology of rock shelters. In: Lugli F, Stopiello A (eds) Proceedings of the 3rd Italian Congress of Ethnoarchaeology, Mondaino (Italy), 17th-19th March, 2004. BAR International Series 1841. Archaeopress, Oxford

Blackford JJ, Innes JB, Hatton JJ, Caseldine CJ (2006) Mid-Holocene environmental change at Black Ridge Brook, Dartmoor, SW England: a new appraisal based on fungal spore analysis. Rev Palaeobot Palynol 141:189-201

Blinnikov MS (2005) Phytoliths in plants and soils of the interior Pacific Northwest, USA. Rev Palaeobot Palynol 135(1):71-98

Booth RK (2002) Testate amoebae as paleoindicators of surface-moisture changes on Michigan peatlands: modern ecology and hydrological calibration. J Paleolimnol 28:329-348

Booth RK, Lamentowicz M, Charman DJ (2010) Preparation and analysis of testate amoebae in peatland paleoenvironmental studies. Article 2. Mires and Peat 7:1-7

Boschian G, Montagnari Kokelj M (2000) Prehistoric shepherds and caves in the Trieste Karst (Northeastern Italy). Geoarchaeology 15: 331-371

Bremond L, Alexandre A, Peyron O, Guiot J (2005) Grass water stress estimated from phytoliths in West Africa. J Biogeogr 32(2):311-327

Brochier JE, Villa P, Giacomarra M (1992) Shepherds and sediments: geo-archaeology of pastoral sites. J Anthropol Archaeol 11:47-102

Brown T, Brown K (2011) Biomolecular archaeology. An introduction. John Wiley \& Sons, Ltd

Brozzetti P (1953) I fieno dei prati-pascoli dei Monti Sibillini. Composizione, digeribilita e valore nutritive. Rivista di Zootecnia $26: 212-217$

Bullock P, Federoff N, Jongerius A, Stoops G, Tursina T (eds) (1985) Handbook for thin section description. Waine Research Publications. Albrighton, Wolverhampton

Canti MG (1997) An investigation of microscopic calcareous spherulites from herbivore dungs. J Archaeol Sci 24:219-231

Carrer F (2013) An ethnoarchaeological inductive model for predicting archaeological site location: a case-study of pastoral settlement patterns in the Val di Fiemme and Val di Sole (Trentino, Italian Alps). J Anthropol Archaeol 32(1):54-62

Carrer F (2017) Interpreting intra-site spatial patterns in seasonal contexts: an ethnoarchaeological case study from the western Alps. J Archaeol Method Theory 24(2):303-327

Carrer F, Walsh K, Mocci F (2020) Ecology, economy, and upland landscapes: socio-ecological dynamics in the Alps during the transition to modernity. Hum Ecol 48:69-84

Catorci A, Vitanzi A, Ballelli S (2010) Phytosociological Study of Beech and Beech-Mixed Woods in Monti Sibillini National Park (Central Apennines, Italy). Hacquetia 9(1):23-75

Chang C (1993) Pastoral transhumance in the Southern Balkans as social ideology: ethnoarchaeological research in Northern Greece. Am Anthropol 95:687-703

Comandini O, Rinaldi A (2004) Tracing megafaunal extinctions with dung fungal spores. Mycologist 18:140-142

Costello E, Svensson E (2018) Historical Archaeologies of Transhumance across Europe. Routledge, London

Courty MA, Goldberg P, Macphail R (1989) Soils and micromorphology in archaeology. Cambridge University Press, Cambridge

Cugny C, Mazier F, Galop D (2010) Modern and fossil non-pollen palynomorphs from the Basque mountains (western Pyrenees, France): the use of coprophilous fungi to reconstruct pastoral activity. Veg Hist Archaeobotany 19:391-408

D'Ottavio P, Scotton M, Ziliotto U (2004) Forage selection by sheep in extensive grazing systems in the Monti Sibillini National Park 
(Central Apennines, Italy). Options Méditerranéennes, Series A 61: 189-192

D'Ottavio P, Scotton M, Ziliotto U (2005) Pastoral value of mountain pastures of Monti Sibillini (Central Apennines, Italy) grazed by sheep. Options Méditerranéennes, series A 67:93-98

De Guio A, Cavicchioli ME (2011) Etnoarcheologia delle malghe: un caso di rilievo. In Lugli et al (eds) Proceedings of the 4th Italian Congress of Ethnoarchaeology, Rome, Italy, 17th-19th May 2006. BAR International Series 2235, Archaeopress, Oxford, pp. 168-183

Dietre B, Gauthier É, Gillet F (2012) Modern pollen rain and fungal spore assemblages from pasture woodlands around Lake Saint-Point (France). Rev Palaeobot Palynol 186:69-89

Égüez N, Makarewicz CA (2018) Carbon isotope ratios of plant nalkanes and microstratigraphy analyses of dung accumulations in a pastoral nomadic winter campsite (Eastern Mongolia). Ethnoarchaeology 10(2):141-158

Égüez N, Zerboni A, Biagetti S (2018) Microstratigraphic analysis on a modern central Saharan pastoral campsite ovicaprine pellets and stabling floors as ethnographic and archaeological referential data. Quat Int 483:180-193

Elliott S, Bendrey R, Whitlam J, Aziz KR, Evans J (2015) Preliminary ethnoarchaeological research on modern animal husbandry in Bestansur, Iraqi Kurdistan: integrating animal, plant and environmental data. Environ Archaeol 20(3):283-303

Ellis MB, Ellis JP (1988) Microfungi on miscellaneous substrates: an identification handbook. Croom Helm, London

Feeser I, O'Connell M (2010) Late Holocene land-use and vegetation dynamics in an upland karst region based on pollen and coprophilous fungal spore analyses: an example from the Burren, western Ireland. Veg Hist Archaeobotany 19:409-426

Fermanelli A (1985) Aree Interne e Sviluppo. Il comprensorio dei Monti Sibillini. Regione Marche-Assessorato all'Ambiente. Ancona

Fernández CA (1993) Fungal palynomorphs and algae from Holocene bottom sediments of Chascomús Lake, Buenos Aires Province, Argentina. Palynology 17:187-200

Fernandez Honaine M, Zucol AF, Osterrieth ML (2006) Phytolith assemblages and systematic associations in grassland species of the SouthEastern Pampean Plains, Argentina. Ann Bot 98(6):1155-1165

Florenzano A, Mercuri AM, Pederzoli A, Torri P, Bosi G, Olmi L, Rinaldi R, Bandini Mazzanti M (2012) The significance of intestinal parasite remains in pollen samples from Medieval pits in the Piazza Garibaldi of Parma, Emilia Romagna, Northern Italy. Geoarchaeol: An Int J 27:34-47

Friesem DE (2016) Geo-ethnoarchaeology in action. J Archaeol Sci 70: $145-157$

Friesem DE, Tsartsidou G, Karkanas P, Shahack-Gross R (2014) Where are the roofs? A geo-ethnoarchaeological study of mud brick structures and their collapse processes, focusing on the identification of roofs. Archaeol Anthropol Sci 6(1):73-92

Gallego L, Distel RA (2004) Phytolith assemblages in grasses native to Central Argentina. Ann Bot 94(6):865-874

Gann GD, Lamb D (eds) (2006) ecological restoration: a mean of conserving biodiversity and sustaining livelihoods (version 1.1). Society for Ecological Restoration International, Tucson, Arizona, USA and IUCN, Gland, Switzerland

Gassiot E, Mazzucco N, Clemente I, Rodríguez A, Ortega D (2012) Circulación e intercambio en el poblamiento y la explotación de la alta montaña del Pirineo en los milenios V-IV ANE. In Borrell M, Borrell F, Bosch J, Clop X, Molist M (eds.). Actas del Congreso Internacional Xarxes al Neolític, Gavà 2-4 febrero 2011. Rubricatum 5, pp. 61-6

Gassiot E, Rodríguez D, Pèlachs A, Pérez-Obiol R, Julià R, Bal MC, Mazzucco N (2014) La alta montaña durante la Prehistoria: 10 años de investigación en el Pirineo catalán occidental. Trab Prehist 71(2):262-282
Gassiot E, Clemente-Conte I, Mazzucco N, García D, Obea L, Rodríguez-Antón R (2016) Surface surveying in high mountain areas, is it possible? Some methodological considerations. Quat Int 402:35-45

Gelorini V, Verbeken A, van Geel B, Cocquyt C, Verschuren D (2011) Modern non-pollen palynomorphs from East African lake sediments. Rev Palaeobot Palynol 164:143-173

Gobbi O (2001) Mercati e mercanti "minori" sull'Appennino marchigiano. Secolo XV. Archivio storico italiano 159:337-357

González-Álvarez D, Fernández-Mier M, López-Gómez P. 2016. An archaeological approach to the brañas: summer farms in the pastures of the Cantabrian Mountains (northern Spain). In: Collis JR, Pearce M, Nicolis F (eds) Summer farms. Seasonal exploitation of the uplands from prehistory to the present. Equinox publishing (Sheffield Archaeological Monographs; 16), Sheffield, pp. 203-219

Graf MT, Chmura GL (2006) Development of modern analogues for natural, mowed and grazed grasslands using pollen assemblages and coprophilous fungi. Rev Palaeobot Palynol 141:139-149

Gur-Arieh S, Madella M, Lavi N, Friesem DE (2018) Potentials and limitations for the identification of outdoor dung plasters in humid tropical environment: a geo-ethnoarchaeological case study from South India. Archaeol Anthropol Sci 11:2683

Heiri O, Lotter AF, Lemcke G (2001) Loss on ignition as a method for estimating organic and carbonate content in sediments: reproducibility and comparability of results. J Paleolimnol 25:101-110

Huntley B, Birks HJB (1983) An atlas of past and present pollen maps for Europe: 0-13000 years ago. University Press, Cambridge

Ingham ER, Wilson MV (1999) The mycorrhizal colonization of six wetland plant species at sites differing in land use history. Mycorrhiza 9:233-235

Jenkins E, Jamjoum K, Al-Nuimat S (2011) Irrigation and phytolith formation: an experimental study. Mithen SJ, Black E (eds) Water, life and civilisation: climate, environment and society in the Jordan Valley, Cambridge University Press/UNESCO, Cambridge/New York, pp. 347-372

Kirk PM, Cannon PF, David JC, Staplers JA (eds) (2001) Ainsworth and Bisby's dictionary of the fungi, 9th edn. Oxford, Oxford University Press

Kołaczek P, Zubek S, Błaszkowski J, Margielewski W (2013) Erosion or plant succession - how to interpret the presence of arbuscular mycorrhizal fungi (Glomeromycota) spores in pollen profiles collected from mires. Rev Palaeobot Palynol 189:29-37

Körner C, Diemer M (1987) In situ photosynthetic responses to light, temperature and carbon dioxide in herbaceous plants from low and high altitude. Funct Ecol 1:179-194

Körner C, Farquhar GD, Roksandic Z (1988) A global survey of carbon isotope discrimination in plants from high altitude. Oecologia (Berlin/West) 74:623-632

Krug JC, Benny GL, Keller HW (2004) Coprophilous fungi. In: Mueller GM, Bills GF, Foster MS (eds) Biodiversity of fungi. Elsevier, Amsterdam, pp 468-499

Lancelotti C, Madella M (2012) The 'invisible' product: developing markers for identifying dung in archaeological contexts. J Archaeol Sci 39:953-963

Levine ND, Ivens V (1970) The coccidian parasites (Protozoa, Sporozoa) of ruminants. Illinois Biological Monographs 44. University of Illinois Press, Urbana, Chicago, London

Liechti K, Biber J-P (2016) Pastoralism in Europe: characteristics and challenges of highland-lowland transhumance. Rev Sci Tech Off Int Epiz 35(2):561-575

López-Merino L, López-Sáez JA, Alba-Sánchez F, Pérez-Díaz S, Carrión JS (2009) 2000 years of pastoralism and fire shaping high-altitude vegetation of Sierra de Gredos in central Spain. Review of Palaeobotany and Palynology, 158(1-2):42-51

Lu H, Liu K (2003) Phytoliths of common grasses in the coastal environments of southeastern USA. Estuar Coast Shelf Sci 58(3):587-600 
Madella M (2007) The silica skeletons from the anthropic deposits. In Whittle A (ed) The Early Neolithic on the great Hungarian plain: investigations of the Körös culture site of Ecsegfalva 23, County Békés. Varia Archeologica Hungarica 21, Institute of Archaeology of the Hungarian Academy of Sciences, Budapest, pp 447-460

Madella M, Powers-Jones AH, Jones MK (1998) A simple method of extraction of opal phytoliths from sediments using a non-toxic heavy liquid. J Archaeol Sci 25(8):801-803

Madella M, Alexandre A, Ball T (2005) International code for phytolith nomenclature 1.0. Ann Bot 96:253-260

Makarov MI (2009) The nitrogen isotopic composition in soils and plants: its use in environmental studies (a review). Eurasian Soil Science 42(12):1335-1347

Marshall F, Reid REB, Goldstein S, Storozum M, Wreschnig A, Hu L, Kiura P, Shahack-Gross R, Ambrose SH (2018) Ancient herders enriched and restructured African grasslands. Nature 561(7723): $387-390$

Mattioni R (1999) La fatica dei campi. Civilta' agricola e pastorale dei Sibillini. Il lavoro editoriale, Ancona

Mazzucco N, Clemente Conte I, Gassiot E (2019) Lost in the mountains? The Cova del Sardo and the Neolithisation of the Southern Central Pyrenees (fifth-third mill. cal BC). Archaeol. Anthropol Sci 11: $1461-1475$

Mercader J, Astudillo F, Barkworth M, Bennett T, Esselmont C, Kinyanjui R, Walde D (2010) Poaceae phytoliths from the Niassa Rift, Mozambique. J Archaeol Sci 37(8):1953-1967

Mercuri AM, Mazzanti MB, Florenzano A, Montecchi MC, Rattighieri E, Torri P (2013) Anthropogenic Pollen Indicators (API) from archaeological sites as local evidence of human-induced environments in the Italian peninsula. Ann Bot 3:143-153

Metcalfe CR (1960) Anatomy of the monocotyledons. 1. Gramineae. Clarendon Press, Oxford

Migliavacca M., Nicosia C. 2011. Geo-Etnoarcheologia di una malga e osservazioni su alcuni parametri chimico-físici di un suolo di ambiente montano ad utilizzo pastorale. In Lugli et al (eds) Proceedings of the 4th Italian Congress of Ethnoarchaeology, Rome, Italy, 17th-19th May 2006. BAR International Series 2235, Archaeopress, Oxford, pp. 184-188

Miller SP (2000) Arbuscular mycorrhizal colonization of semi-aquatic grasses along a wide hydrologic gradient. New Phytol 145:145-155

Miller RF, Rose JA (1995) Historic expansion of Juniperus occidentalis (Western juniper) in southeastern Oregon. Gt Basin Nat 55(1):4

Miola A (2012) Tools for non-pollen palynomorphs (NPPs) analysis: a list of quaternary NPP types. Rev Palaeobot Palynol 186:142-161

Moore PD, Webb JA, Collison ME (1991) Pollen analysis. Blackwell Scientific Publications, Oxford

Morandi LF, Branch NP (2018) Long-range versus short-range prehistoric pastoralism. Potential of palaeoecological proxies and a new record from western Emilia, northern Apennines, Italy. In Pelisiak A, Nowak M, Astaloș C (eds.) People and the mountains. Archaeopress Publishing Ltd, pp. 47-60

Moulia B (1994) The biomechanics of leaf rolling. Biomimetics 2:267-281

Mudie PJ, Leroy SAG, Marret F, Gerasimenko N, Kholeif SEA, Sapelko T, Filipova-Marinova M. (2011) Non-pollen palynomorphs: indicators of salinity and environmental change in the Caspian-Black Sea-Mediterranean corridor. In Buynevich IV et al (eds) Geology and geoarchaeology of the Black Sea Region: beyond the flood hypothesis. Geological Society of America Special Paper 473:89 115

Nandris J (1990) The Balkan dimension of Highland zone in pastoralism. Rivista di studi liguri 56:99-108

Natelhoffer KJ, Fry B (1988) Controls on natural nitrogen-15 and carbon13 abundances in forest soil organic matter. Soil Sci Soc Am J 52: $1633-1640$

Nicolis F, Mottes E, Bassetti M, Castiglioni E, Rottoli M, Ziggiotti S (2016) Going up the mountain! Exploitation of the Trentino highlands as summer farms during the Bronze Age: the Dosso Rotondo site at Storo (northern Italy). In Collis J, Pearce M, Nicolis F (eds) Summer farms. Seasonal exploitation of the uplands from prehistory to the present. Sheffield Archaeological Monographs 16. JR Collis Publications, Sheffield, pp. 108-137

Novello A, Barboni D (2015) Grass inflorescence phytoliths of useful species and wild cereals from sub-Saharan Africa. J Archaeol Sci 59:10-22

Novello A, Barboni D, Berti-Equille L, Mazur JC, Poilecot P, Vignaud P (2012) Phytolith signal of aquatic plants and soils in Chad, Central Africa. Rev Palaeobot Palynol 178:43-58

Padiglione V (2012) Villaggi di capanne nei Lepini. Una prospettiva etnoarcheologica, Roma: Edizione Kappa

Pedrotti F (1995) I pioppeti di Pioppo tremulo dell'Appennino centrale. Studi Trentini di Scienze Naturali, Acta Biologica, 70:99-105

Pedrotti F (2001) Environmental systems, vegetation belts and potential vegetation of the Monti Sibillini (Central Italy). Oecologia Montana 10:13-18

Pelisiak A, Nowak M, Astalos C (eds) (2018) People in the mountains current approaches to the archaeology of mountainous landscapes. Archaeopress Publishing Ltd, Oxford

Piperno DR (2006) Phytoliths: a comprehensive guide for archaeologists and paleoecologists. AltaMira Press, Lanham

Portillo M, Albert RM (2011) Husbandry practices and livestock dung at the Numidian site of Althiburos (el Médéina, Kef Governorate, northern Tunisia): the phytolith and spherulite evidence. J Archaeol Sci 38:3224-3233

Portillo M, Ball T, Manwaring J (2006) Morphometric analysis of inflorescence phytoliths produced by Avena sativa L. and Avena strigos Schreb. Econ Bot 60(2):121-129

Portillo M, Kadowaki S, Nishiaki Y, Albert RM (2014) Early Neolithic household behavior at Tell Seker al-Aheimar (Upper Khabur, Syria): a comparison to ethnoarchaeological study of phytoliths and dung spherulites. J Archaeol Sci 42:107-118

Ramsey MN, Rosen A (2016) Wedded to wetlands: exploring Late Pleistocene plant-use in the Eastern Levant. Quat Int 396:5-19

Rickerl DH, Sancho FO, Ananth S (1994) Vesicular-arbuscular endomycorrhizal colonization of wetland plants. J Environ Qual 23:913-916

Rodríguez-Antón D, Gassiot E, Mazzucco N et al (2016) Del medio natural al paisaje social: la construcción de los paisajes pastorales. Ocupación de las zonas de alta montaña en los Pirineos centrales de Cataluña desde el Mesolítico a la Edad del Bronce (c. 9000-1000 cal ANE) Munibe. Antropologia-Arkeologia, 67:325-337

Rosen AM (1992) Preliminary identification of silica skeletons from Near Eastern archaeological sites: an anatomical approach. In Rapp JrG, Mulholland SC (eds) Phytolith systematics: emerging issues. Springer Science \& Business Media, pp. 129-147

Ryan P (2011) Plants as material culture in the Near Eastern Neolithic: perspectives from the silica skeleton artifactual remains at Çatalhöyük. J Anthropol Archaeol 30(3):292-305

Schofield JE, Edwards KJ, McMullen JA (2007) Modern pollenvegetation relationships in subarctic southern Greenland and the interpretation of fossil pollen data from the Norse landnám. J Biogeogr 34(3):473-488

Scotton M, Da Ronch F, D'Ottavio P, Ziliotto U (2005) Excrement distribution by different grazing animals in mountain pastures of Cansiglio upland plain (NE Italy). In Molina Alcaide E, Ben Salem H, Biala K, Morand-Fehr P (eds.) Sustainable grazing, nutritional utilization and quality of sheep and goat products, Zaragoza: CIHEAM, Options Méditerranéennes: Série A. Séminaires Méditerranéens, 67, pp. 251-254

Shahack-Gross R (2017) Animal gathering enclosures. In Nicosia C, Stoops G (eds) Archaeological soil and sediment micromorphology, pp. 265-280. John Wiley \& Sons, Ltd 
Shahack-Gross R, Finkelstein I (2008) Subsistence practices in an arid environment: a geoarchaeological investigation in an Iron Age site, the Negev Highlands, Israel. J Archaeol Sci 35(4):965-982

Shahack-Gross R, Marshall F, Weiner S (2003) Geo-ethnoarchaeology of pastoral sites: the identification of livestock enclosures in abandoned Maasai settlements. J Archaeol Sci 30(4):439-459

Shahack-Gross R, Marshall F, Ryan K, Weiner S (2004) Reconstruction of spatial organization in abandoned Maasai settlements: implications for site structure in the Pastoral Neolithic of East Africa. J Archaeol Sci 31(10):1395-1411

Shahack-Gross R, Simons A, Ambrose SH (2008) Identification of pastoral sites using stable nitrogen and carbon isotopes from bulk sediment samples: a case study in modern and archaeological pastoral settlements in Kenya. J Archaeol Sci 35:983-990

Skibo JM (2009) Archaeological theory and snake-oil peddling: the role of ethnoarchaeology in archaeology. Ethnoarchaeology 1:27-56

Spengler RN (2019) Dung burning in the archaeobotanical record of West Asia: where are we now? Veg Hist Archaeobotany 28(3):215-227

Stoops G (2003) Guidelines for analysis and description of soil and regolith thin sections. Soil Science Society of America, Inc., Madison

Stoops G, Marcelino V, Mees F (2010) Interpretation of micromorphological features of soils and regoliths. Elsevier, Amsterdam

Strömberg CA (2004) Using phytolith assemblages to reconstruct the origin and spread of grass-dominated habitats in the Great Plains during the late Eocene to early Miocene. Palaeogeogr Palaeocl 207:239-275

Tubb HJ, Hodson MJ, Hodson GC (1993) The inflorescence papillae of the Triticeae: a new tool for taxonomic and archaeological research. Ann Bot 72:537-545

Twiss PC, Suess E, Smith RM (1969) Morphological classification of grass phytoliths. Soil Sci Soc Am J 33:109-115 van Geel B (1978) A palaeoecological study of Holocene peat bog sections in Germany and the Netherlands, based on the analysis of pollen, spores and macro- and microscopic remains of fungi, algae cormophytes and animals. Rev Palaeobot Palynol 25:1-120

van Geel B, Aptroot A (2006) Fossil ascomycetes in Quaternary deposits. Nova Hedwigia 82(3-4):313-329

van Geel B, Bos JM, Pals JP (1983) Archaeological and palaeoecological aspects of a medieval house terp in a reclaimed raised bog area in North Holland. Ber Rijksd Oudheidkd Bodemonderz 33:419-444

van Geel B, Buurman J, Brinkkemper O, Schelvis J, Aptroot A, van Reenen G, Hakbijl T (2003) Environmental reconstruction of a Roman Period settlement site in Uitgeest (The Netherlands), with special reference to coprophilous fungi. J Archaeol Sci 30(7):873-883

Vánky K (1994) European Smut Fungi. Gustav Fischer, Jena

Vergès JM, Allué E, Fontanals M (2016) Shepherds and caves. Quat Int 414:199-201

Wallace M, Charles M (2013) What goes in doesn't always come out: the impact of the ruminant digestive system of sheep on plant material, and its importance for the interpretation of dung-derived archaeobotanical assemblages. Environ Archaeol 18:18-30

Walsh K (2013) The Archaeology of Mediterranean Landscapes: HumanEnvironment Interaction from the Neolithic to the Roman Period. Cambridge University Press

Weishampel PA, Bedfor BL (2006) Wetland dicots and monocots differ in colonization by arbuscular mycorrhizal fungi and dark septate endophytes. Mycorrhiza 16:495-502

Zurro D, García-Granero JJ, Lancelotti C, Madella M (2016) Directions in current and future phytolith research. J Archaeol Sci 68:112-117

Publisher's note Springer Nature remains neutral with regard to jurisdictional claims in published maps and institutional affiliations. 